\title{
Nitrate retention and removal in Mediterranean streams bordered by contrasting land uses: $a^{15} \mathbf{N}$ tracer study
}

\author{
D. von Schiller ${ }^{1,}$, E. Martí ${ }^{1}$, and J. L. Riera ${ }^{2}$ \\ ${ }^{1}$ Limnology Group, Centre d'Estudis Avançats de Blanes, Consejo Superior de Investigaciones Científicas, \\ 17300 Blanes, Spain \\ ${ }^{2}$ Departament d'Ecologia, Facultat de Biología, Universitat de Barcelona, 08028 Barcelona, Spain \\ *now at: Leibniz-Institute of Freshwater Ecology and Inland Fisheries, Müggelseedamm 301, 12561 Berlin, Germany
}

Received: 5 August 2008 - Published in Biogeosciences Discuss.: 27 August 2008

Revised: 11 December 2008 - Accepted: 19 December 2008 - Published: 11 February 2009

\begin{abstract}
We used ${ }^{15} \mathrm{~N}$-labelled nitrate $\left(\mathrm{NO}_{3}^{-}\right)$additions to investigate pathways of nitrogen $(\mathrm{N})$ cycling at the wholereach scale in three stream reaches with adjacent forested, urban and agricultural land areas. Our aim was to explore among-stream differences in: (i) the magnitude and relative importance of $\mathrm{NO}_{3}^{-}$retention (i.e. assimilatory uptake) and removal (i.e. denitrification), (ii) the relative contribution of the different primary uptake compartments to $\mathrm{NO}_{3}^{-}$retention, and (iii) the regeneration, transformation and export pathways of the retained $\mathrm{N}$.

Streams varied strongly in $\mathrm{NO}_{3}^{-}$concentration, which was highest in the agricultural stream and lowest in the forested stream. The agricultural stream also showed the lowest dissolved oxygen (DO) concentration and discharge. Standing stocks of primary uptake compartments were similar among streams and dominated by detritus compartments (i.e. fine and coarse benthic organic matter). Metabolism was net heterotrophic in all streams, although the degree of heterotrophy was highest in the agricultural stream.

The $\mathrm{NO}_{3}^{-}$uptake length was shortest in the agricultural stream, intermediate in the urban stream, and longest in the forested stream. Conversely, the $\mathrm{NO}_{3}^{-}$mass-transfer velocity and the areal $\mathrm{NO}_{3}^{-}$uptake rate were highest in the urban stream. Denitrification was not detectable in the forested stream, but accounted for $9 \%$ and $68 \%$ of total $\mathrm{NO}_{3}^{-}$uptake in the urban and the agricultural stream, respectively. The relative contribution of detritus compartments to $\mathrm{NO}_{3}^{-}$assimilatory uptake was greatest in the forested and lowest in the agricultural stream. In all streams, the retained $\mathrm{N}$ was rapidly
\end{abstract}

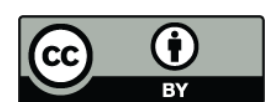

Correspondence to: D. von Schiller (schiller@ceab.csic.es) regenerated back to the water column. Due to a strong coupling between regeneration and nitrification, most retained $\mathrm{N}$ was exported from the experimental reaches in the form of $\mathrm{NO}_{3}^{-}$.

This study provides evidence of fast in-stream $\mathrm{N}$ cycling, although the relative importance of $\mathrm{N}$ retention and removal varied considerably among streams. Results suggest that permanent $\mathrm{NO}_{3}^{-}$removal via denitrification may be enhanced over temporary $\mathrm{NO}_{3}^{-}$retention via assimilatory uptake in heterotrophic human-altered streams characterized by high $\mathrm{NO}_{3}^{-}$and low DO concentrations.

\section{Introduction}

Streams and rivers have the ability to store, transform and remove nutrients during downstream transport, which results in variations in the form and amount of nutrients delivered to downstream ecosystems (Alexander et al., 2000; Peterson et al., 2001; Mulholland et al., 2008). Nitrate $\left(\mathrm{NO}_{3}^{-}\right)$, the most abundant form of dissolved inorganic nitrogen $(\mathrm{N})$ found in freshwaters, can be temporarily retained or permanently removed during downstream transport (Bernot and Dodds, 2005).

Retention of $\mathrm{NO}_{3}^{-}$occurs via assimilatory uptake by stream benthic organisms, often referred to as primary uptake compartments (i.e. those compartments that take up dissolved nutrients directly from the water column). The relative contribution of autotrophs (i.e. algae, macrophytes, and bryophytes) and heterotrophs (i.e. bacteria and fungi) to assimilatory uptake is influenced by the availability of nutrients, light and organic matter (Allan, 1995). The $\mathrm{NO}_{3}^{-}$assimilated by the primary uptake compartments is transferred

Published by Copernicus Publications on behalf of the European Geosciences Union. 
to consumers at higher trophic levels and regenerated back to the water column as ammonium $\left(\mathrm{NH}_{4}^{+}\right)$via mineralization and excretion. As it is transported downstream, the regenerated $\mathrm{NH}_{4}^{+}$is again taken up by the biota or transformed to $\mathrm{NO}_{3}^{-}$via nitrification, thus completing a whole cycle or spiral (Newbold, 1996).

Removal of $\mathrm{NO}_{3}^{-}$occurs via denitrification, a microbial dissimilatory process in which dissolved $\mathrm{NO}_{3}^{-}$is reduced to gaseous forms of $\mathrm{N}$, which results in a permanent $\mathrm{N}$ lost from the ecosystem (Seitzinger et al., 1988). Denitrification in streams takes place in the sediments, and is generally controlled by the availability of oxygen, organic carbon and $\mathrm{NO}_{3}^{-}$(Holmes et al., 1996; Kemp and Dodds, 2002). This simple perspective of the processes involved in the fate of $\mathrm{NO}_{3}^{-}$in streams can be further complicated by alternative dissimilatory uptake processes (Burgin and Hamilton, 2007), and abiotic $\mathrm{N}$ adsorption and burial (Bernot and Dodds, 2005).

Nitrogen pollution in aquatic ecosystems can cause acidification, eutrophication, and impairment of aquatic organisms, as well as problems to human health and economy (Camargo and Alonso, 2006). Because $\mathrm{NO}_{3}^{-}$retention and removal differentially affect the form and amount of $\mathrm{N}$ exported downstream, it is critical to understand these pathways and to evaluate their relative contribution to total $\mathrm{NO}_{3}^{-}$uptake. In addition, we know little about the role of streams as a source of $\mathrm{N}_{2} \mathrm{O}$, an intermediary product of denitrification that is considered an important greenhouse gas and a catalyzer of ozone destruction (Beaulieu et al., 2008).

Nitrogen uptake in streams has been mostly studied using nutrient enrichment experiments (Stream Solute Workshop, 1990; Webster and Valett, 2006), whereas particular processes such as nitrification and denitrification have been mainly investigated using incubation experiments (Holmes et al., 1996; Kemp and Dodds, 2002; Inwood et al., 2005). Both approaches, however, show evident methodological constraints. For instance, nutrient additions may underestimate actual uptake rates at ambient levels (Mulholland et al., 2002; Dodds et al., 2002), whereas measurements from incubation experiments are difficult to extrapolate to the wholereach scale (Dodds et al., 2000). More recently, $\mathrm{N}$ retention and removal pathways have been explored using ${ }^{15} \mathrm{~N}$ tracer addition techniques, which allow quantifying processes simultaneously occurring in a stream at the whole-reach scale and at ambient conditions, while avoiding the limitations of enrichment experiments and incubations.

Various studies have used ${ }^{15} \mathrm{~N}$ tracer additions to investigate $\mathrm{N}$ retention and removal in reference headwater streams evidencing the high reactivity of these ecosystems (e.g. Peterson et al., 1997; Hall et al., 1998; Peterson et al., 2001; Mulholland et al., 2004). More recent studies have expanded our knowledge on these processes using ${ }^{15} \mathrm{~N}$ tracer additions in streams influenced by various human activities (e.g., Boehlke et al., 2004; Grimm et al., 2005; Bernot et al., 2006;
Simon et al., 2007; O'Brien et al., 2007; Mulholland et al., 2008). Results from these studies indicate that human activities reduce stream nutrient uptake efficiency (i.e. uptake relative to nutrient flux) through the combined effect of stream channel modifications, increased nutrient loading, and other forms of water pollution that inhibit biological communities responsible for nutrient uptake. However, it is still unclear how changes derived from different land uses influence both the relative contribution of retention and removal processes to total $\mathrm{N}$ uptake and the regeneration, transformation and export of the retained $\mathrm{N}$.

In addition, most previous studies have been conducted in streams from temperate regions of North America, yet studies in different bioclimatic regions are needed for a global understanding of $\mathrm{N}$ dynamics in streams. Mediterranean catchments, such as the ones in this study, differ from those in temperate North America because: i) they have a longer history of human impact, ii) they often have mixed land uses so that streams situated in urban and agricultural areas often have catchments dominated by second growth forests, and iii) they may be more susceptible to human impacts due to the natural deficit of water resources (Alvarez-Cobelas et al., 2005). Moreover, because many of these catchments are relatively small and located next to the sea, headwater streams are of greatest importance for the retention and removal of $\mathrm{N}$ that is quickly exported to downstream coastal ecosystems.

In this study, we used ${ }^{15} \mathrm{NO}_{3}^{-}$tracer additions to investigate pathways of $\mathrm{N}$ cycling at the whole-reach scale in three stream reaches situated within the same Mediterranean catchment but differing in the dominant land use type adjacent to the stream (i.e. forested, agricultural and urban). Specifically, we aimed to explore among-stream differences in: i) the magnitude and relative importance of $\mathrm{NO}_{3}^{-}$retention (i.e. assimilatory uptake) and removal (i.e. denitrification), ii) the relative contribution of the different primary uptake compartments to $\mathrm{NO}_{3}^{-}$retention, and iii) the regeneration, transformation and export pathways of the retained $\mathrm{N}$.

\section{Methods}

\subsection{Study sites}

This study was conducted in the catchment of the river $\mathrm{La}$ Tordera (Catalonia, NE Spain), with an area of $868.5 \mathrm{~km}^{2}$ and dominated by siliceous geology. Climate in this region is typically Mediterranean, with warm, dry summers and mild, humid winters. Within this catchment, we selected three closely located streams that drained mostly forested catchments but differed in the land use type adjacent to the study reaches (i.e. forested, urban and agricultural, Fig. 1). From the stream Santa $\mathrm{Fe}$ (hereafter referred to as the forested stream) we selected a reach located at $1120 \mathrm{~m}$ a.s.l. within a beech (Fagus sylvatica) forest in the Montseny Natural Protected Area. From the stream Gualba (hereafter referred to as 
the urban stream) we selected a reach located at $168 \mathrm{~m}$ a.s.1. in a park of a town with $\sim 1000$ inhabitants. Finally, from the stream Sant Celoni (hereafter referred to as the agricultural stream) we selected a reach located at $246 \mathrm{~m}$ a.s.1 and bordered by a mixture of olive tree (Olea europaea) and pine (Pinus halepensis) plantations. Although this agricultural reach is intermittent, water flow did not cease until after the end of the experiments. In the forested stream riparian vegetation was dominated by beech, with some stems of common elder (Sambucus nigra) and a poorly developed herbaceous understory. In the other streams riparian vegetation consisted mainly of alder (Alnus glutinosa) and sycamore (Platanus hispanica), with a denser herbaceous understory, especially in the agricultural stream. All three experimental reaches showed relatively well preserved channel morphology, were riffle-run dominated, and cobbles were the most abundant substrate type. Reach length was $262 \mathrm{~m}$ in the forested stream and $400 \mathrm{~m}$ in both the urban and the agricultural stream. The experiments were conducted from July to August 2004, a period characterized by low base flow and full riparian cover.

\subsection{Field methods}

Tracer ${ }^{15} \mathrm{NO}_{3}^{-}$addition experiments followed procedures adapted from Mulholland et al. (2004). A solution of ${ }^{15} \mathrm{NO}_{3}^{-}$ (as $99 \%$ enriched $\mathrm{K}^{15} \mathrm{NO}_{3}^{-}$) in conjunction with chloride (as $\mathrm{NaCl}$ ) was released at the top of the reach at a constant rate $\left(20 \mathrm{~mL} \mathrm{~min}^{-1}\right)$ using a Masterflex (Vernon Hills, Illinois, USA) L/S battery-powered peristaltic pump. Additions started at midnight (00:00) and lasted for $\sim 12 \mathrm{~h}$. The amount of $\mathrm{K}^{15} \mathrm{NO}_{3}^{-}$added to each stream was calculated to produce a target $\delta^{15} \mathrm{~N}$ enrichment of $10000 \%$ of the $\mathrm{NO}_{3}^{-}$in the stream water. The solution was released sufficiently upstream to guarantee complete lateral mixing at the first sampling station.

The passage of the conservative tracer (i.e. chloride) was automatically recorded at the first sampling station and at the bottom of the reach every $10 \mathrm{~s}$ using WTW (Weilheim, Germany) 340i portable conductivity meters connected to Campbell Scientific (Logan, Utah, USA) CR510 data loggers. We measured conductivity and collected water samples at six stations along the reach before the addition (i.e. background sampling). During the addition, we measured conductivity and collected water samples at the same stations at 06:00 (i.e. first plateau sampling) and 11:00 (i.e. second plateau sampling) to determine $\mathrm{NO}_{3}^{-}$uptake parameters for night and day, respectively. One day after the addition was stopped (i.e. post-24 h sampling), we measured conductivity and collected water samples at the same stations and at an additional upstream station. In the agricultural stream, we decided to bring forward the post- $24 \mathrm{~h}$ sampling to $7 \mathrm{~h}$ after the end of the addition to avoid an imminent rain event. Nonetheless, conductivity along the reach was at background levels at the time of sampling, indicating that the conserva-

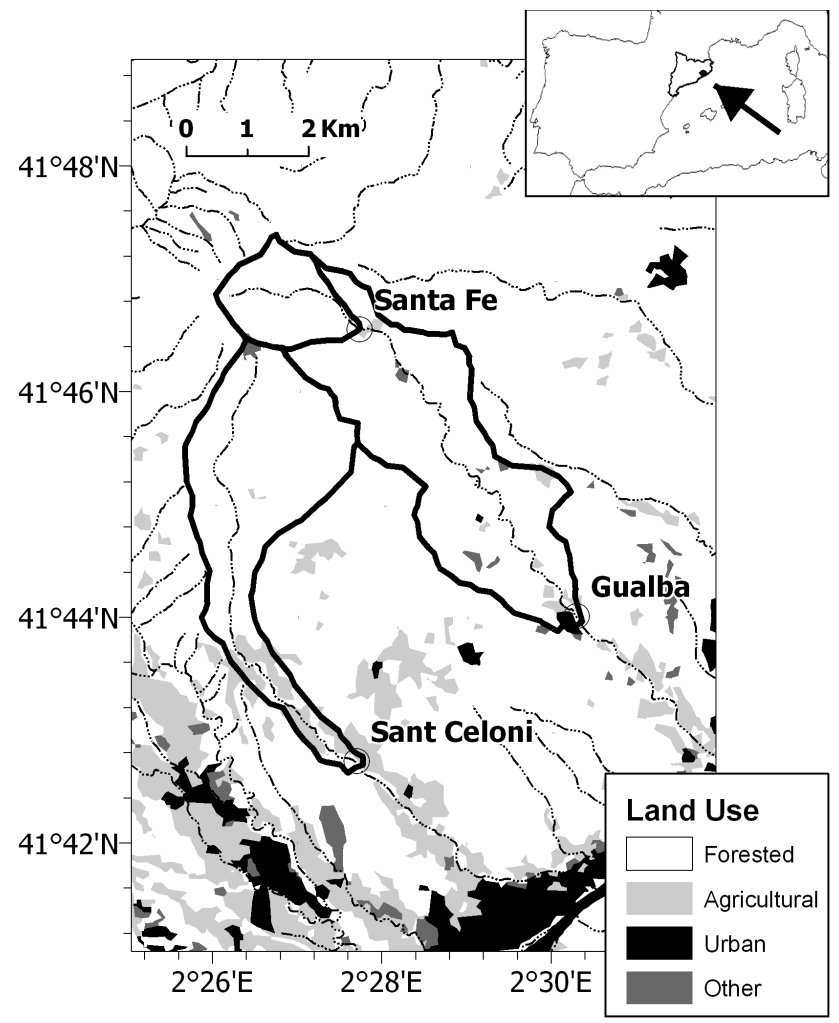

Fig. 1. Geographical location and land use characteristics of the study streams and their respective sub-catchments within the catchment of the river La Tordera (Catalonia, NE Spain). Land use types were grouped into forested (including all types of forests), agricultural (including irrigated and dry land crops), urban (including towns, residential areas, industrial zones and commercial zones), and other (including water impoundments, grasslands and areas without vegetation).

tive tracer had already left the experimental reach. Finally, we measured conductivity and collected water samples at the upstream and the most downstream station two days (i.e. post- $48 \mathrm{~h}$ sampling) and three days (i.e. post- $72 \mathrm{~h}$ sampling) after the addition was stopped.

All water samples were immediately filtered through ashed Albet (Barcelona, Spain) FVF glass fiber filters $(0.7 \mu \mathrm{m}$ pore size). Filtered samples for nutrient chemistry $\left(40 \mathrm{~mL}\right.$, two replicates per station) and ${ }^{15} \mathrm{NO}_{3}^{-}(0.5 \mathrm{~L}$, two replicates per station) were stored on ice in the field, and then refrigerated at $4^{\circ} \mathrm{C}$ or frozen in the laboratory until further processing and analysis. Filtered samples for ${ }^{15} \mathrm{NH}_{4}^{+}$(3 to $4 \mathrm{~L}$, one sample per station) were immediately processed as explained in the laboratory methods section.

Background and plateau water samples of dissolved ${ }^{15} \mathrm{~N}_{2}$ and ${ }^{15} \mathrm{~N}_{2} \mathrm{O}$ (40 mL, two replicates per station) were collected at 10 stations along the reach coinciding in time with water sampling following procedures by Hamilton and Ostrom (2007). Water samples were collected in $60-\mathrm{mL}$ plastic syringes fitted with stopcocks, taking care not to include bubbles in the samples. With the sample syringe submersed 
under water, $20 \mathrm{~mL}$ of high purity $\mathrm{He}$ were added to each syringe. Syringes were then shaken for $\sim 10 \mathrm{~min}$ to allow equilibration of the $\mathrm{N}$-gas into the He space. Afterwards, the He space was collected in evacuated 12-mL Labco (High Wycombe, UK) Type 3 exetainers. The exetainers were stored in water-filled centrifuge tubes until analysis.

Standing stocks of primary uptake compartments were estimated using patch-specific samplings at the seven (six downstream + one upstream) water sampling stations two days after the end of the ${ }^{15} \mathrm{NO}_{3}^{-}$addition. Coarse benthic organic matter (CBOM), mostly consisting of leaves and small wood sticks, and water-submerged alder roots were sampled by collecting all material found within a $0.04 \mathrm{~m}^{2}$ metal frame. Surface and sub-surface fine benthic organic matter (FBOM) was sampled using a syringe to collect an aliquot of the material suspended by manual agitation of the surface $(\sim 1 \mathrm{~cm})$ and subsurface $(\sim 3$ to $5 \mathrm{~cm})$ sediment in a known volume within a $0.05 \mathrm{~m}^{2}$ plastic corer. Collected FBOM samples were filtered onto ashed pre-weighted FVF glass fiber filters. We sampled suspended particulate organic matter (SPOM) by filtering a known volume of water onto ashed pre-weighted FVF glass fiber filters. Bryophytes and filamentous algae were sampled by scraping material found within a $0.002 \mathrm{~m}^{2}$ plastic frame. Epilithon was sampled by scraping randomly collected cobbles and filtering onto ashed pre-weighted FVF glass fiber filters. The cobble surface was estimated by covering with aluminum foil and applying a weight to area relationship. Composite samples for ${ }^{15} \mathrm{~N}$ analysis (three to six replicates per station) were collected from all compartments at the seven water sampling stations during the post- $24 \mathrm{~h}$ sampling using the same methods as for standing stock sampling. Additional SPOM samples for ${ }^{15} \mathrm{~N}$ analysis were collected from the upstream and the most downstream station during the post- $48 \mathrm{~h}$ and the post- $72 \mathrm{~h}$ sampling.

Whole-stream metabolism was estimated in each stream on the day of the ${ }^{15} \mathrm{NO}_{3}^{-}$addition using the open-system, single station approach (Bott, 2006). Dissolved oxygen (DO) concentration and temperature were recorded at the bottom of the study reach at 10 -min intervals during a $24 \mathrm{~h}$ period with a WTW (Weilheim, Germany) 340i portable oxygen meter. During the same period, photosynthetically active radiation (PAR) was measured every $10 \mathrm{~min}$ with a Skye (Powys, UK) SKP215 quantum sensor connected to a Campbell Scientific (Logan, Utah, USA) CR510 data logger. Prior to measurements, the DO probe was calibrated following the manufacturer's instructions.

On the day before the addition we determined the wetted width $(w)$ and percent reach coverage of different substrate types (i.e. mud, sand, pebbles, cobbles, rocks, boulders, bedrock) using cross-sectional transects located every $25 \mathrm{~m}$ along the reach. The percent reach coverage of stream habitats (riffle, run, and pool) and primary uptake compartments was visually estimated on the same date at 5-m intervals along the reach.

\subsection{Laboratory methods}

Stream water samples were analyzed for $\mathrm{NO}_{3}^{-}, \mathrm{NO}_{2}^{-}$, and soluble reactive phosphorus (SRP) concentrations on a Bran+Luebbe (Nordersted, Germany) TRAACS $2000 \mathrm{Au}-$ toanalyzer. The concentration of $\mathrm{NH}_{4}^{+}$was analyzed on a Skalar (Breda, The Netherlands) $\mathrm{San}^{+}$Auto-analyzer. All nutrient analyses were performed following standard colorimetric methods (APHA, 1995). The concentration of dissolved organic carbon (DOC) was determined on a Shimadzu (Tokyo, Japan) TOC-VCSH analyzer.

The ${ }^{15} \mathrm{~N}$ content of stream water $\mathrm{NH}_{4}^{+}$was determined following procedures adapted from Holmes et al. (1998). Filtered samples were amended with $3.0 \mathrm{~g}$ of $\mathrm{MgO}, 50 \mathrm{~g}$ of $\mathrm{NaCl}$, and a Teflon filter packet. The Teflon filter packet was constructed by sealing a $1-\mathrm{cm}$ diameter ashed Whatman (Kent, UK) GF/D glass fiber filter, acidified with $25 \mu \mathrm{L}$ of $2.5 \mathrm{~m} \mathrm{KHSO}_{4}$, within a packet made of two pieces of Teflon plumbing tape. Finally, samples were incubated in a shaker at $40^{\circ} \mathrm{C}$ for three to four weeks to allow for diffusion of $\mathrm{NH}_{3}$ onto the acidified filter. The ${ }^{15} \mathrm{~N}$ content of stream water $\mathrm{NO}_{3}^{-}$was determined using an adaptation of the method by Sigman et al. (1997). Dissolved $\mathrm{NH}_{4}^{+}$was removed and stream water samples were concentrated (volume depending on the $\mathrm{N}$ content of each sample) by adding $3.0 \mathrm{~g}$ of $\mathrm{MgO}$ and $5.0 \mathrm{~g}$ of $\mathrm{NaCl}$ and boiling. Resulting samples $(\sim 0.1 \mathrm{~L})$ were then transferred to acid-washed plastic bottles to which $0.5 \mathrm{~g}$ $\mathrm{MgO}$ and $0.5 \mathrm{~g}$ Devarda's alloy and a Teflon filter packet were added. The samples were incubated at $60^{\circ} \mathrm{C}$ for $48 \mathrm{~h}$ to reduce $\mathrm{NO}_{3}^{-}$to $\mathrm{NH}_{4}^{+}$, and then placed on a shaker for seven days to allow for diffusion of ammonia $\left(\mathrm{NH}_{3}\right)$ onto the acidified filter. At the end of the processing, filters from ${ }^{15} \mathrm{NO}_{3}^{-}$ and ${ }^{15} \mathrm{NH}_{4}^{+}$samples were removed from the bottles, placed in scintillation vials, dried in a desiccator for four days, encapsulated in tins, and stored until analysis. Various sets of blanks and standards of known concentration for ${ }^{15} \mathrm{NO}_{3}^{-}$and ${ }^{15} \mathrm{NH}_{4}^{+}$samples were run for each addition.

Samples for standing stocks of all primary uptake compartments were oven-dried at $60^{\circ} \mathrm{C}$, weighted to the nearest $0.1 \mathrm{mg}$ on a Sartorius (Goettingen, Germany) MC1 analytical balance, and combusted at $450^{\circ} \mathrm{C}$ to estimate ash free dry mass (AFDM). To calculate whole-reach standing stocks $\left(\mathrm{g} \mathrm{AFDM} \mathrm{m}^{-2}\right.$ ) of the different primary uptake compartments, we corrected the patch-specific estimates by the percent reach coverage of each compartment. Bryophytes (only the tips), filamentous algae, root, and CBOM samples for ${ }^{15} \mathrm{~N}$ analysis were oven-dried at $60^{\circ} \mathrm{C}$, ground to a fine powder, weighted to the nearest $0.001 \mathrm{mg}$ on a MettlerToledo (Greifensee, Switzerland) MX5 microbalance, encapsulated in tins, and stored until analysis. For FBOM, SPOM and epilithon samples (on pre-weighted glass fiber filters), discs of a known surface area (diameter $=1 \mathrm{~cm}$ ) were cut out from the previously oven-dried filters and processed as the rest of samples. 
Encapsulated samples of ${ }^{15} \mathrm{NO}_{3}^{-},{ }^{15} \mathrm{NH}_{4}^{+}$, and primary uptake compartments were analyzed at the University of California Stable Isotope Facility (Davis, California, USA). The content (as a percent of dry mass) and the stable isotope ratios of $\mathrm{C}$ and $\mathrm{N}$ were measured by continuous flow isotope ratio mass spectrometry (20-20 mass spectrometer; PDZEuropa, Northwich, UK) after sample combustion in an on-line elemental analyzer (PDZEuropa ANCA-GSL). We estimated the $\mathrm{C}$ content of wood and root samples, for which the detection limit of the mass spectrometer was exceeded, as $45 \%$ of dry mass based on unpublished data from nearby streams. One set of $\mathrm{N}$-gas samples was analyzed for ${ }^{15} \mathrm{~N}_{2} \mathrm{O}$ on a Finnigan (Sacramento, California, USA) MAT 251 Isotope Ratio Mass Spectrometer at the same stable isotope laboratory. The other set of $\mathrm{N}$-gas samples was analyzed for ${ }^{15} \mathrm{~N}_{2}$ on a multicollector CV Instruments (Manchester, UK) Isoprime Mass Spectrometer at the Michigan State University Stable Isotope Laboratory (Lansing, Michigan, USA).

\subsection{Parameter calculations}

Breakthrough curves of conductivity at the bottom of the reach were analyzed by visual inspection with a onedimensional transport with inflow and storage model (OTIS; Runkel, 1998) to estimate stream hydraulic characteristics, including discharge, cross-sectional area $(A)$ and crosssectional transient storage zone area $\left(A_{s}\right)$. The chloride breakthrough curve at the first sampling station was used as the upstream boundary condition. Before applying the OTIS model to the conductivity time-curve data, we calculated the Damkohler number (DaI) to evaluate whether the selected reach length was appropriate (Wagner and Harvey, 1997). DaI values ranged between 0.7 and 3.4, which is considered acceptable for the model application (Hall et al., 2002; Ensign and Doyle, 2005). Mean reach depth was calculated as $A / w$. Water transient storage was reported as the ratio $A_{s} / A$

We calculated daily rates of gross primary production (GPP) and ecosystem respiration (ER) by integrating the DO measurements at the bottom of the reach during the $24 \mathrm{~h}$ period following Bott (2006). Percent DO saturation was estimated using DO and temperature together with a standard altitude-air pressure algorithm to correct for site altitude. Reaeration coefficients were estimated based on the surface renewal model (Owens, 1974, Table 1). Instantaneous respiration rates at night were extrapolated to $24 \mathrm{~h}$ to estimate ER. We computed GPP by integrating the difference between the measured net DO change (corrected by the reaeration flux) and the extrapolated day-time respiration. GPP and ER were multiplied by the mean reach depth to obtain areal estimates.

The fractional $\mathrm{NO}_{3}^{-}$uptake rate per unit distance $\left(k_{W}\right.$ $\mathrm{NO}_{3}^{-}, \mathrm{m}^{-1}$ ) was estimated from the regression of the $\mathrm{ln}-$ transformed tracer ${ }^{15} \mathrm{NO}_{3}^{-}$flux versus distance downstream with data from the plateau samplings (Mulholland et al., 2004). The tracer ${ }^{15} \mathrm{NO}_{3}^{-}$flux at each station was calculated by multiplying the background-corrected ${ }^{15} \mathrm{NO}_{3}^{-}$concentra-
Table 1. Physical, chemical, and metabolism characteristics of the study streams during the ${ }^{15} \mathrm{NO}_{3}^{-}$additions.

\begin{tabular}{|c|c|c|c|}
\hline & $\begin{array}{c}\text { Santa Fe } \\
\text { (forested) }\end{array}$ & $\begin{array}{l}\text { Gualba } \\
\text { (urban) }\end{array}$ & $\begin{array}{c}\text { Sant Celoni } \\
\text { (agricultural) }\end{array}$ \\
\hline \multicolumn{4}{|l|}{ Physical } \\
\hline Discharge $\left(\mathrm{Ls}^{-1}\right)$ & 8.8 & 11.6 & 1.2 \\
\hline Velocity $\left(\mathrm{cm} \mathrm{s}^{-1}\right)$ & 5.1 & 6.7 & 2.4 \\
\hline Width (m) & 3.7 & 3 & 2 \\
\hline Depth (cm) & 4.6 & 5.8 & 2.5 \\
\hline$A_{S}: A$ & 0.29 & 0.06 & 0.08 \\
\hline Temperature $\left({ }^{\circ} \mathrm{C}\right)$ & 12.2 & 19.7 & 19.8 \\
\hline PAR (moles $\left.\mathrm{m}^{-2} \mathrm{~d}^{-1}\right)$ & 1.8 & 2.6 & 2.3 \\
\hline \multicolumn{4}{|l|}{ Chemical } \\
\hline Conductivity $\left(\mu \mathrm{S} \mathrm{cm}^{-1}\right)$ & 62 & 156 & 101 \\
\hline Dissolved oxygen $\left(\mathrm{mg} \mathrm{L}^{-1}\right)$ & 9 & 8.2 & 5.7 \\
\hline $\mathrm{NO}_{3}^{-}\left(\mu \mathrm{g} \mathrm{NL}^{-1}\right)$ & 172 & 394 & 601 \\
\hline $\mathrm{NO}_{2}^{-}\left(\mu \mathrm{g} \mathrm{NL}^{-1}\right)$ & 2 & 4 & 3 \\
\hline $\mathrm{NH}_{4}^{+}\left(\mu \mathrm{g} \mathrm{NL}^{-1}\right)$ & 7 & 9 & 8 \\
\hline $\operatorname{SRP}\left(\mu \mathrm{g} \mathrm{PL}^{-1}\right)$ & 16 & 8 & 22 \\
\hline $\operatorname{DOC}\left(\mathrm{mg} \mathrm{L}^{-1}\right)$ & 1.2 & 2.4 & 2 \\
\hline \multicolumn{4}{|l|}{ Metabolism } \\
\hline Oxygen reaeration rate $\left(\mathrm{m}^{-1}\right)$ & 0.04 & 0.03 & 0.12 \\
\hline $\operatorname{GPP}\left(\mathrm{g} \mathrm{O}_{2} \mathrm{~m}^{-2} \mathrm{~d}^{-1}\right)$ & 0.7 & 2 & 4.6 \\
\hline $\mathrm{ER}\left(\mathrm{g} \mathrm{O}_{2} \mathrm{~m}^{-2} \mathrm{~d}^{-1}\right)$ & 1.3 & 5.1 & 32.9 \\
\hline GPP:ER & 0.54 & 0.39 & 0.14 \\
\hline
\end{tabular}

tion by discharge at each station. Station-specific discharge was calculated from the dilution of the conservative tracer along the reach. The inverse of $k_{W} \mathrm{NO}_{3}^{-}$is the $\mathrm{NO}_{3}^{-}$uptake length $\left(S_{w} \mathrm{NO}_{3}^{-} ; \mathrm{m}\right)$, which was converted to the $\mathrm{NO}_{3}^{-}$ mass-transfer velocity $\left(V_{f} \mathrm{NO}_{3}^{-} ; \mathrm{cm} \mathrm{s}^{-1}\right)$ as the stream specific discharge $(Q / w)$ divided by $S_{w} \mathrm{NO}_{3}^{-}$. The areal $\mathrm{NO}_{3}^{-}$ uptake rate $\left(U \mathrm{NO}_{3}^{-} ; \mu \mathrm{g} \mathrm{m}^{2} \mathrm{~s}^{-1}\right)$, the mass of $\mathrm{NO}_{3}^{-}$taken up from the water column per unit streambed area and time, was calculated as $V_{f} \mathrm{NO}_{3}^{-}$multiplied by the mean ambient $\mathrm{NO}_{3}^{-}$ concentration. Data from the first and the second plateau sampling were used to calculate night and day $k_{W} \mathrm{NO}_{3}^{-}$, respectively. Differences between day and night $k_{W} \mathrm{NO}_{3}^{-}$were tested with a $t$-test for the comparison of slopes (Fowler and Cohen, 1990) and applying a Bonferroni correction. Mean $k_{W} \mathrm{NO}_{3}^{-}$for each stream was calculated as the average of night and day values.

The fractional denitrification rates per unit distance via $\mathrm{N}_{2}$ $\left(k_{\text {DEN }} \mathrm{N}_{2} ; \mathrm{m}^{-1}\right)$ and $\mathrm{N}_{2} \mathrm{O}\left(k_{\text {DEN }} \mathrm{N}_{2} \mathrm{O} ; \mathrm{m}^{-1}\right)$ production were estimated by separately fitting the longitudinal tracer flux of ${ }^{15} \mathrm{~N}_{2}$ and ${ }^{15} \mathrm{~N}_{2} \mathrm{O}$ from the plateau samplings to the denitrification model proposed by Mulholland et al. (2004) using the Microsoft (Redmond, Washington, USA) Excel 2003 Solver tool. The tracer flux of ${ }^{15} \mathrm{~N}_{2}$ or ${ }^{15} \mathrm{~N}_{2} \mathrm{O}$ at each station was calculated by multiplying the background-corrected ${ }^{15} \mathrm{~N}_{2}$ or ${ }^{15} \mathrm{~N}_{2} \mathrm{O}$ concentration by discharge at each station. Only data from stations with a significant tracer ${ }^{15} \mathrm{~N}$ in $\mathrm{N}_{2}$ or $\mathrm{N}_{2} \mathrm{O}$ (defined as $\delta^{15} \mathrm{~N}$ values greater than the upper $97.5 \%$ confidence 
interval of background values) were used (Mulholland et al., 2008). The reaeration rates of $\mathrm{N}_{2}$ and $\mathrm{N}_{2} \mathrm{O}$ were estimated based on the surface renewal model (Owens, 1974) correcting for the respective Schmidt numbers. Total fractional denitrification rate per unit distance $\left(k_{\mathrm{DEN}}\right.$ Total; $\left.\mathrm{m}^{-1}\right)$ was calculated as the sum of $k_{\text {DEN }} \mathrm{N}_{2}$ and $k_{\text {DEN }} \mathrm{N}_{2} \mathrm{O}$. The denitrification length $\left(S_{\mathrm{DEN}} ; \mathrm{m}\right)$, the denitrification mass-transfer velocity $\left(V_{\mathrm{fDEN}} ; \mathrm{cm} \mathrm{s}^{-1}\right)$ and the areal denitrification rate $\left(U_{\mathrm{DEN}} ; \mu \mathrm{g} \mathrm{N} \mathrm{m}^{-2} \mathrm{~s}^{-1}\right)$ were calculated from $k_{\mathrm{DEN}}$ as previously indicated for $k_{W} \mathrm{NO}_{3}^{-}$. Data from the first and the second plateau sampling in each stream were used to calculate night and day $k_{\mathrm{DEN}}$, respectively. Mean $k_{\mathrm{DEN}}$ for each stream was calculated as the average of the night and day $k_{\mathrm{DEN}}$.

The compartment-specific $\mathrm{NO}_{3}^{-}$assimilatory uptake rate of each primary uptake compartment at each station was calculated as the reach-weighted mass of ${ }^{15} \mathrm{~N}$ tracer per $\mathrm{m}^{2}$ of each compartment divided by the time of the addition $(\sim 12 \mathrm{~h})$ and the fraction of ${ }^{15} \mathrm{~N}$ in the stream water $\mathrm{NO}_{3}^{-}$flux. The areal $\mathrm{NO}_{3}^{-}$assimilatory uptake rate by all primary uptake compartments together $\left(U_{\mathrm{BIO}} ; \mu \mathrm{g} \mathrm{N} \mathrm{m}^{-2} \mathrm{~s}^{-1}\right)$ was calculated as the sum of the mean compartment-specific $\mathrm{NO}_{3}^{-}$assimilatory uptake rates. We used the mean reach $\mathrm{NO}_{3}^{-}$concentration and $Q / w$ to convert $U_{\mathrm{BIO}}$ to the assimilatory uptake mass-transfer velocity $\left(V_{\mathrm{fBIO}}\right)$, the assimilatory uptake length $\left(S_{\mathrm{BIO}}\right)$ and the fractional assimilatory uptake rate per unit distance $\left(k_{\mathrm{BIO}}\right)$. Finally, we estimated the proportion of the total $\mathrm{NO}_{3}^{-}$assimilatory uptake (i.e. the difference between $k_{W}$ $\mathrm{NO}_{3}^{-}$and $\left.k_{\mathrm{DEN}}\right)$ accounted for by $k_{\mathrm{BIO}}$.

We calculated the $\mathrm{N}$ turnover rate $\left(\mathrm{s}^{-1}\right)$ for each primary uptake compartment by dividing the compartment-specific $\mathrm{NO}_{3}^{-}$assimilatory uptake rate $\left(\mu \mathrm{g} \mathrm{N} \mathrm{m}^{-2} \mathrm{~s}^{-1}\right)$ by the mass of $\mathrm{N}$ per $\mathrm{m}^{2}$ of each compartment. This measure allows for comparisons of the role of the different primary uptake compartments in $\mathrm{N}$ regeneration. However, we should take this measurement as an approximation to real $\mathrm{N}$ turnover for several reasons: this measurement does not take into account uptake of dissolved $\mathrm{N}$ forms other than $\mathrm{NO}_{3}^{-}$, the additions were not long enough to reach a steady state, and much of the pool of N, especially in the CBOM compartments, is not involved in $\mathrm{N}$ cycling.

Because the post-24h longitudinal tracer fluxes of ${ }^{15} \mathrm{NH}_{4}^{+}$ and ${ }^{15} \mathrm{NO}_{3}^{-}$showed a similar tendency, the fractional $\mathrm{N}$ regeneration rates per unit time via $\mathrm{NH}_{4}^{+}$release $\left(k_{\mathrm{AM}} ; \mathrm{s}^{-1}\right)$ and its subsequent transformation to $\mathrm{NO}_{3}^{-}$via nitrification $\left(K_{\mathrm{NIT}} ; \mathrm{s}^{-1}\right)$ were estimated by separately fitting both fluxes to an ammonification-nitrification model, based on the nitrification model proposed by Mulholland et al. (2000). We used the rate of decline in total biomass ${ }^{15} \mathrm{~N}$ with distance as the source of labeled $\mathrm{N}$ that can contribute to regeneration. The tracer flux of ${ }^{15} \mathrm{NH}_{4}^{+}$and ${ }^{15} \mathrm{NO}_{3}^{-}$at each station was calculated by multiplying the background-corrected ${ }^{15} \mathrm{NH}_{4}^{+}$and ${ }^{15} \mathrm{NO}_{3}^{-}$concentration by discharge at each station. Because $\mathrm{NH}_{4}^{+}$is expected to be taken up preferentially over $\mathrm{NO}_{3}^{-}$, we optimized a solution for $k_{\mathrm{AM}}$ with the Solver Tool using the condition of a fractional $\mathrm{NH}_{4}^{+}$uptake rate $\left(k_{W} \mathrm{NH}_{4}^{+}\right) \geq k_{W}$ $\mathrm{NO}_{3}^{-}$. To estimate $K_{\mathrm{NIT}}$, the mean $k_{W} \mathrm{NO}_{3}^{-}$value calculated from the ${ }^{15} \mathrm{NO}_{3}^{-}$decline at plateau was used. We assumed that all labeled ${ }^{15} \mathrm{NO}_{3}^{-}$at the post- $24 \mathrm{~h}$ sampling must originate from nitrification of the labeled ${ }^{15} \mathrm{NH}_{4}^{+}$released by the biota; thus the total fractional regeneration rate per unit distance $\left(k_{\mathrm{REG}} ; \mathrm{s}^{-1}\right)$ was calculated as the sum of $k_{\mathrm{AM}}$ and $k_{\mathrm{NIT}}$.

Export of the retained ${ }^{15} \mathrm{~N}$ from the experimental reach as $\mathrm{NO}_{3}^{-}, \mathrm{NH}_{4}^{+}$, and SPOM was calculated using data from the post- $24 \mathrm{~h}$, post $-48 \mathrm{~h}$, and post- $72 \mathrm{~h}$ samplings. The total export tracer ${ }^{15} \mathrm{~N}$ flux for each sampling date was estimated as the sum of $\mathrm{NO}_{3}^{-}, \mathrm{NH}_{4}^{+}$, and $\mathrm{SPOM}{ }^{15} \mathrm{~N}$ fluxes.

\section{Results}

\subsection{Physical and chemical characteristics}

Hydrological characteristics were typical of the summer base flow period in all streams; however, discharge was almost one order of magnitude lower in the agricultural stream than in the other two streams (Table 1). Water temperature was lower in the forested stream than in the other two streams due to its location at a higher altitude (Table 1). Solar radiation (as PAR) was low and similar among streams reflecting the influence of the relatively well developed riparian canopies (Table 1). Differences in nutrient concentrations among streams were mainly associated to $\mathrm{NO}_{3}^{-}$. The concentration of $\mathrm{NO}_{3}^{-}$in the agricultural and the urban streams was 3.5 and 2.3 times higher, respectively, than in the forested stream (Table 1). The daily mean DO concentration was $\sim 1.5$ times lower in the agricultural stream than in the urban and forested streams (Table 1). Mean \% DO saturation was $99 \%$ in the forested, $95 \%$ in the urban and $68 \%$ in the agricultural stream. Physical and chemical characteristics remained relatively constant during the experiments, although diel changes (i.e. lower discharge and higher temperature during the day) were observed, especially in the agricultural stream.

\subsection{Stream metabolism and standing stocks}

We observed differences among streams in metabolism, which were more pronounced for ER. Daily rates of GPP were 6.6 and 2.9 times higher in the agricultural and urban streams, respectively, than in the forested stream (Table 1). Daily rates of ER were 25.3 and 3.9 times higher in the agricultural and urban streams, respectively, than in the forested stream (Table 1). In all streams the GPP:ER ratio was $<1$, indicating the importance of heterotrophic activity in these well shaded streams (Table 1). However, the degree of heterotrophy (i.e. the inverse of the GPP:ER ratio) was 3.9 and 1.4 times higher in the agricultural and urban streams, respectively, than in the forested stream (Table 1). 
Table 2. Reach-weighted standing-stock $\left(\mathrm{g}_{\mathrm{AFDM} \mathrm{m}}{ }^{-2}\right)$, percent nitrogen $(\% \mathrm{~N}$ of dry mass), and carbon to nitrogen ratio (C:N by mass) of primary uptake compartments in the study reaches. Data reported are means with SE in parenthesis.

\begin{tabular}{|c|c|c|c|c|c|c|c|c|c|c|c|c|c|c|c|c|c|c|}
\hline \multirow[b]{3}{*}{ Leaves } & \multicolumn{6}{|c|}{ Santa Fe (forested) } & \multicolumn{6}{|c|}{ Gualba (urban) } & \multicolumn{6}{|c|}{ Sant Celoni (agricultural) } \\
\hline & \multicolumn{2}{|c|}{ AFDM } & \multicolumn{2}{|c|}{$\% \mathrm{~N}$} & \multicolumn{2}{|c|}{$\mathrm{C}: \mathrm{N}$} & \multicolumn{2}{|c|}{ AFDM } & \multicolumn{2}{|c|}{$\% \mathrm{~N}$} & \multicolumn{2}{|c|}{$\mathrm{C}: \mathrm{N}$} & \multicolumn{2}{|c|}{ AFDM } & \multicolumn{2}{|c|}{$\% \mathrm{~N}$} & \multicolumn{2}{|c|}{$\mathrm{C}: \mathrm{N}$} \\
\hline & 10.8 & $(7.8)$ & 1.5 & $(0.1)$ & 29.6 & (1.7) & 11.4 & $(2.6)$ & 1.9 & $(0.2)$ & 24.5 & (2.6) & 1.8 & $(0.9)$ & 2.0 & $(0.02)$ & 19.5 & $(0.2)$ \\
\hline Wood & 0.4 & $(0.2)$ & 0.8 & $(0.1)$ & 58.4 & * & 5.8 & $(0.03)$ & 0.9 & $(0.1)$ & 49.0 & $*$ & 6.9 & $(4.2)$ & 1.3 & $(0.05)$ & 33.6 & $*$ \\
\hline Surface FBOM & 26.1 & (11.6) & 1.3 & $(0.1)$ & 17.7 & $(0.8)$ & 19.7 & $(5.3)$ & 0.4 & $(0.02)$ & 12.1 & $(0.1)$ & 10.2 & (1.6) & 0.6 & $(0.01)$ & 11.5 & $(0.05)$ \\
\hline Subsurface FBOM & 39.7 & $(16.4)$ & 1.0 & $(0.2)$ & 17.0 & $(0.4)$ & 46.9 & $(16.9)$ & 0.4 & $(0.1)$ & 12.3 & (0.4) & 59.4 & $(17.7)$ & 0.5 & $(0.02)$ & 10.3 & $(0.1)$ \\
\hline Epilithon & 1.2 & $(0.2)$ & 1.4 & $(0.1)$ & 7.5 & $(0.1)$ & 2.0 & $(0.4)$ & 1.2 & $(0.1)$ & 6.5 & $(0.1)$ & 0.6 & $(0.5)$ & 0.7 & $(0.02)$ & 5.8 & $(0.03)$ \\
\hline Bryophytes & 0.2 & $(0.2)$ & 2.1 & $(0.2)$ & 18.4 & $(0.9)$ & - & & - & & - & & - & & - & & - & \\
\hline Filamentous & 0.04 & $(0.01)$ & 4.5 & $(0.1)$ & 8.8 & $(0.1)$ & 0.1 & $(0.04)$ & 5.3 & $(0.1)$ & 7.5 & $(0.1)$ & - & & - & & - & \\
\hline Roots & & & & & & & 0.6 & $(0.1)$ & 2.2 & $(0.1)$ & 20.9 & $*$ & 0.4 & $(0.3)$ & 2.4 & $(0.04)$ & 18.4 & $*$ \\
\hline Total AFDM & 78.5 & $(36.3)$ & & & & & 86.0 & (25.3) & & & & & 78.9 & (25.1) & & & & \\
\hline
\end{tabular}

* \% C assumed to be $45 \%$ of dry mass

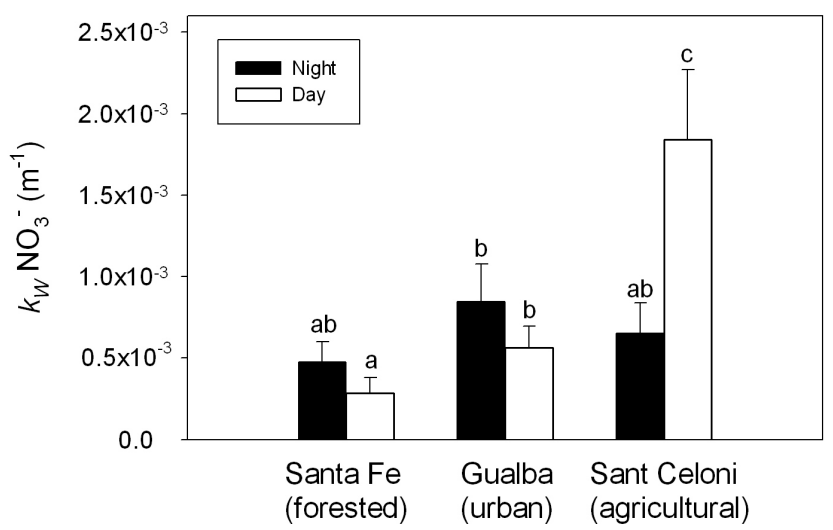

Fig. 2. Fractional $\mathrm{NO}_{3}^{-}$uptake rates per unit distance $\left(k_{W} \mathrm{NO}_{3}^{-}\right.$; $\mathrm{m}^{-1}$ ) in each stream during the night plateau (white columns) and the day plateau (black columns). Error bars are $\pm \mathrm{SE}$ calculated from the error of the linear regression between ${ }^{15} \mathrm{NO}_{3}^{-}$flux and distance downstream. All regressions had $n=6$ cases, except the forested stream $(n=5)$ and the urban stream $(n=4)$ at day due to lost samples or outliers. Significant $(\mathrm{p}<0.05)$ differences among streams and between day and night within each stream are marked with different letters.

The total standing stock of primary uptake compartments was similar among streams and dominated by detritus compartments (i.e. FBOM and CBOM; Table 2). The standing stock of FBOM, especially the subsurface fraction, was the largest compartment in all streams. Leaves were the largest CBOM fraction in the forested and urban stream, whereas the wood fraction was larger in the agricultural stream. The standing stock of compartments dominated by primary producers, such as epilithon, bryophytes (only found in the forested stream), and filamentous algae (only found in the forested and urban streams), as well as the standing stock of submersed alder roots (only found in the urban and agricultural streams), were relatively small. In all streams, the $\% \mathrm{~N}$ content was highest for filamentous algae followed by roots, bryophytes, and leaves, whereas the remaining compartments showed an $\mathrm{N}$ content $\leq 2 \%$ (Table 2). The $\mathrm{C}: \mathrm{N}$ ratio was higher for detritus compartments and alder roots than for compartments dominated by primary producers (bryophytes, filamentous algae, and epilithon) (Table 2). For each compartment, the $\mathrm{C}: \mathrm{N}$ ratio was highest in the forested stream, intermediate in the urban stream, and lowest in the agricultural stream.

\subsection{Nitrate removal and retention pathways}

Mean $k_{w} \mathrm{NO}_{3}^{-}$was 3.3 and 1.8 times higher (i.e. mean $S_{w}$ $\mathrm{NO}_{3}^{-}$lower) in the agricultural and urban streams, respectively, than in the forested stream (Fig. 2, Table 3). However, among-stream differences in $k_{w} \mathrm{NO}_{3}^{-}$were only significant during day-time (Fig. 2). Significant differences in $\mathrm{NO}_{3}^{-}$uptake between day and night were only found in the agricultural stream, in which $k_{W} \mathrm{NO}_{3}^{-}$was three-fold higher during the day than during the night (Fig. 2). Mean $V_{f} \mathrm{NO}_{3}^{-}$and mean $U \mathrm{NO}_{3}^{-}$were highest in the urban stream (Table 3).

Mean $k_{\mathrm{DEN}}, V_{\mathrm{fDEN}}$ and $U_{\mathrm{DEN}}$ were below detection level in the forested stream, intermediate in the urban stream and highest in the agricultural stream. Denitrification accounted for $9 \%$ and $68 \%$ of total $\mathrm{NO}_{3}^{-}$uptake in the urban and agricultural stream, respectively (Fig. 3; Table 3). Denitrification tended to be higher at day than at night in the two streams where denitrification was measurable (Fig. 3). Overall, $\mathrm{N}_{2} \mathrm{O}$ production accounted for $<3 \%$ of total denitrification (Table 3). However, the ${ }^{15} \mathrm{~N}$ tracer was only detected in the form of $\mathrm{N}_{2} \mathrm{O}$ in the urban stream at night (Fig. 3).

The ${ }^{15} \mathrm{~N}$ tracer was detected in all primary uptake compartments collected during the experiments. However, in the urban stream $k_{\mathrm{BIO}}$ accounted for only $15 \%$ of the total assimilatory uptake calculated from the difference between $k_{W}$ $\mathrm{NO}_{3}^{-}$and $k_{\mathrm{DEN}}$, whereas it accounted for $92 \%$ and $100 \%$ in the forested and agricultural stream, respectively (Table 3). $U_{\mathrm{BIO}}$ was similar among streams, but the relative contribution of the different primary uptake compartments to $U_{\mathrm{BIO}}$ differed considerably among streams (Fig. 4). The contribution of detritus compartments to $\mathrm{NO}_{3}^{-}$assimilatory uptake was highest in the forested stream, intermediate in the urban stream, and lowest in the agricultural stream. Conversely, 
Table 3. Summary of total $\mathrm{NO}_{3}^{-}$uptake, denitrification and $\mathrm{NO}_{3}^{-}$assimilatory uptake in the study reaches. Parameters of total $\mathrm{NO}_{3}^{-}$uptake and denitrification were calculated from the mean of night and day values shown in Figs. 2 and 3. Parameters of $\mathrm{NO}_{3}^{-}$assimilatory uptake were calculated from the $\mathrm{NO}_{3}^{-}$uptake rates of primary uptake compartments shown in Fig. 4.

\begin{tabular}{|c|c|c|c|c|}
\hline & & $\begin{array}{l}\text { Santa Fe } \\
\text { (forested) }\end{array}$ & $\begin{array}{l}\text { Gualba } \\
\text { (urban) }\end{array}$ & $\begin{array}{l}\text { Sant Celoni } \\
\text { (agricultural) }\end{array}$ \\
\hline \multicolumn{5}{|l|}{ Total $\mathrm{NO}_{3}^{-}$uptake } \\
\hline & $k_{W} \mathrm{NO}_{3}^{-}\left(\mathrm{m}^{-1}\right)$ & $3.82 \times 10^{-4}$ & $7.05 \times 10^{-4}$ & $1.25 \times 10^{-3}$ \\
\hline & $S_{W} \mathrm{NO}_{3}^{-}(\mathrm{m})$ & 2620 & 1419 & 802 \\
\hline & $V_{f} \mathrm{NO}_{3}^{-}\left(\mathrm{cm} \mathrm{s}^{-1}\right)$ & $9.07 \times 10^{-5}$ & $2.71 \times 10^{-4}$ & $7.47 \times 10^{-5}$ \\
\hline & $U \mathrm{NO}_{3}^{-}\left(\mu \mathrm{g} \mathrm{N} \mathrm{m}^{-2} \mathrm{~s}^{-1}\right)$ & $1.56 \times 10^{-1}$ & 1.07 & $4.49 \times 10^{-1}$ \\
\hline \multicolumn{5}{|l|}{ Denitrification } \\
\hline & $k_{\mathrm{DEN}} \mathrm{N}_{2}\left(\mathrm{~m}^{-1}\right)$ & 0 & $5.98 \times 10^{-5}$ & $8.24 \times 10^{-4}$ \\
\hline & $k_{\text {DEN }} \mathrm{N}_{2} \mathrm{O}\left(\mathrm{m}^{-1}\right)$ & 0 & $1.48 \times 10^{-7}$ & $1.85 \times 10^{-5}$ \\
\hline & $k_{\text {DEN }}$ Total $\left(\mathrm{m}^{-1}\right)$ & 0 & $5.99 \times 10^{-5}$ & $8.42 \times 10^{-4}$ \\
\hline & $S_{\text {DEN }}$ Total $(\mathrm{m})$ & - & 16681 & 1187 \\
\hline & $V_{\mathrm{fDEN}}$ Total $\left(\mathrm{cm} \mathrm{s}^{-1}\right)$ & 0 & $2.30 \times 10^{-5}$ & $4.50 \times 10^{-5}$ \\
\hline & $U_{\text {DEN }}$ Total $\left(\mu \mathrm{g} \mathrm{N} \mathrm{m}^{-2} \mathrm{~s}^{-1}\right)$ & 0 & $8.68 \times 10^{-2}$ & $2.70 \times 10^{-1}$ \\
\hline & $\%$ of total $\mathrm{NO}_{3}^{-}$uptake & 0 & 8.5 & 67.6 \\
\hline \multicolumn{5}{|l|}{ Assimilatory uptake } \\
\hline & $k_{\mathrm{BIO}}\left(\mathrm{m}^{-1}\right)$ & $3.50 \times 10^{-4}$ & $9.92 \times 10^{-5}$ & $4.27 \times 10^{-4}$ \\
\hline & $S_{\mathrm{BIO}}(\mathrm{m})$ & 2860 & 10077 & 2342 \\
\hline & $V_{\mathrm{fBIO}}\left(\mathrm{cm} \mathrm{s}^{-1}\right)$ & $8.30 \times 10^{-5}$ & $3.82 \times 10^{-5}$ & $2.50 \times 10^{-5}$ \\
\hline & $U_{\mathrm{BIO}}\left(\mu \mathrm{g} \mathrm{N} \mathrm{m}^{-2} \mathrm{~s}^{-1}\right)$ & $1.43 \times 10^{-1}$ & $1.50 \times 10^{-1}$ & $1.50 \times 10^{-1}$ \\
\hline & $\%$ of total $\mathrm{NO}_{3}^{-}$uptake & 91.6 & 14.1 & 34.3 \\
\hline
\end{tabular}

the contribution of epilithon and alder roots showed the opposite pattern, together accounting for up to $60 \%$ of $U_{\mathrm{BIO}}$ in the agricultural stream. The contribution of CBOM was generally less important than that of FBOM, except in the urban stream, in which leaves accounted for $26 \%$ of $U_{\mathrm{BIO}}$. Both bryophytes (only found in the forested stream) and filamentous algae (only found in the forested and urban streams) represented $<0.1 \%$ of $U_{\mathrm{BIO}}$.

Epilithon showed the highest $\mathrm{N}$ turnover rate, exceeded only by alder roots in the urban stream, whereas detritus compartments tended to show intermediate $\mathrm{N}$ turnover rates in all streams (Fig. 4). Where present, bryophytes and filamentous algae presented the lowest $\mathrm{N}$ turnover rates.

\subsection{Nitrogen regeneration pathways}

The ${ }^{15} \mathrm{~N}$ tracer was detected in the form of $\mathrm{NH}_{4}^{+}$and $\mathrm{NO}_{3}^{-}$ in all streams during the post- $24 \mathrm{~h}$ sampling (Fig. 5). The longitudinal data of ${ }^{15} \mathrm{NH}_{4}^{+}$and ${ }^{15} \mathrm{NO}_{3}^{-}$were well fitted by the ammonification-nitrification model, especially in the forested and urban streams. The Solver tool gave the best fit for $k_{\mathrm{AM}}$ when $k_{W} \mathrm{NH}_{4}^{+}$and $k_{W} \mathrm{NO}_{3}^{-}$were identical. The highest $k_{\mathrm{AM}}$ was found in the urban stream and the lowest in the agricultural stream, whereas $k_{\text {NIT }}$ showed the opposite pattern (Table 4 , Fig. 5). In all streams, $k_{\text {NIT }}$ was over one order of magnitude greater than $k_{\mathrm{AM}}$., thus accounting for $95 \%$ to $100 \%$ of $k_{\text {REG }}$ in all streams (Table 4 ).

\subsection{Nitrogen export pathways}

Results from the post-addition samplings at the most downstream station showed that part of the retained ${ }^{15} \mathrm{~N}$ was being exported out of the experimental reaches in both dissolved and particulate forms (Fig. 6). Nitrate accounted for $>90 \%$ of total exported ${ }^{15} \mathrm{~N}$ flux in all reaches except in the urban stream, in which $\mathrm{NH}_{4}^{+}$became the most important ${ }^{15} \mathrm{~N}$ export pathway over time, accounting for up to $96 \%$ of total export $72 \mathrm{~h}$ after the addition was stopped (Fig. 6). Conversely, in the forested and agricultural stream $\mathrm{NH}_{4}^{+}$accounted for $<9 \%$ of total exported ${ }^{15} \mathrm{~N}$ flux throughout the experiment. SPOM was a relatively unimportant export pathway, accounting for $<0.4 \%$ of total ${ }^{15} \mathrm{~N}$ export in all study reaches and sampling times. 


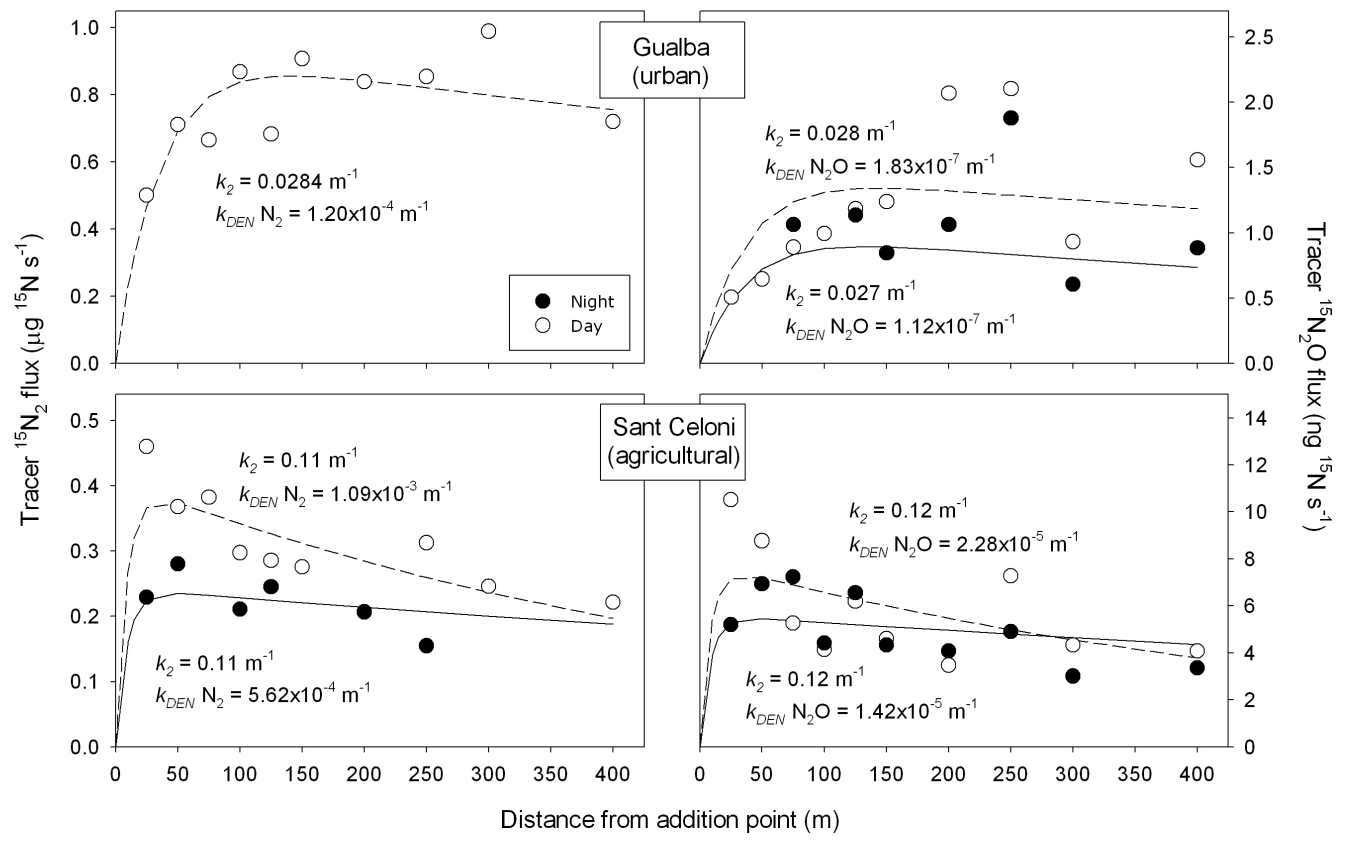

Fig. 3. Plot of the tracer ${ }^{15} \mathrm{~N}_{2}$ (left) and tracer ${ }^{15} \mathrm{~N}_{2} \mathrm{O}$ (right) flux versus distance downstream from the addition point in the two streams were denitrification was detected. Closed symbols represent samples from the night plateau; open symbols represent samples from the day plateau. Solid lines (for night plateau) and dashed lines (for day plateau) show the best fit of the denitrification model to the tracer ${ }^{15} \mathrm{~N}$-gas flux data using the estimated reaeration rates $\left(k_{2} ; \mathrm{m}^{-1}\right)$ and the fractional $\mathrm{NO}_{3}^{-}$uptake rate per unit distance $\left(k_{W} \mathrm{NO}_{3}^{-} ; \mathrm{m}^{-1}\right)$ shown in Fig. 2. Notice the different units of the tracer ${ }^{15} \mathrm{~N}_{2}$ and tracer ${ }^{15} \mathrm{~N}_{2} \mathrm{O}$ fluxes.

\section{Discussion}

\subsection{Total $\mathrm{NO}_{3}^{-}$uptake}

The study streams were moderately efficient in taking up $\mathrm{NO}_{3}^{-}$, with $S_{W} \mathrm{NO}_{3}^{-}$ranging from a few hundred to a few thousand meters. Values of $V_{f} \mathrm{NO}_{3}^{-}$, a nutrient uptake metric commonly used for among-stream comparisons because it corrects $S_{W}$ for differences in stream size (Webster and Valett, 2006), were in the lower range of values reported from 72 streams subjected to various land uses across USA and Puerto Rico (Mulholland et al., 2008). Our Vf $\mathrm{NO}_{3}^{-}$values, however, were generally higher than those reported from streams affected by wastewater treatment plant inputs (e.g., Ruggiero et al., 2006; Gücker and Pusch, 2006) and lower than those reported from reference headwater streams (e.g., Davis and Minshall, 1999; Simon et al., 2005; Hoellein et al., 2007).

Significant diel changes in $\mathrm{NO}_{3}^{-}$uptake were only found in the agricultural stream, which showed higher $\mathrm{NO}_{3}^{-}$uptake at day than at night. Previous studies in reference headwater streams showed similar findings and attributed higher $\mathrm{NO}_{3}^{-}$uptake during daylight to higher photoautotrophic activity (Fellows et al., 2006; Mulholland et al., 2006). This was likely the case in the agricultural stream, which showed the highest GPP among the study streams. In addition, the agricultural stream showed higher temperature and lower dis-
Table 4. Summary of $\mathrm{N}$ regeneration rates in the study reaches estimated with results from the ammonification-nitrification model shown in Fig. 4.

\begin{tabular}{lccc}
\hline & $\begin{array}{c}\text { Santa Fe } \\
\text { (forested) }\end{array}$ & $\begin{array}{c}\text { Gualba } \\
\text { (urban) }\end{array}$ & $\begin{array}{c}\text { Sant Celoni } \\
\text { (agricultural) }\end{array}$ \\
\hline $\begin{array}{l}\text { Ammonium release } \\
k_{\mathrm{AM}}\left(\mathrm{s}^{-1}\right)\end{array}$ & $5.48 \times 10^{-5}$ & $7.59 \times 10^{-5}$ & $1.88 \times 10^{-5}$ \\
\hline $\begin{array}{l}\text { Nitrification } \\
k_{\mathrm{NIT}}\left(\mathrm{s}^{-1}\right)\end{array}$ & $4.89 \times 10^{-3}$ & $1.52 \times 10^{-3}$ & $8.21 \times 10^{-2}$ \\
\hline $\begin{array}{l}\text { Total } \mathrm{N} \\
\text { regeneration }\end{array}$ & & & \\
$k_{\mathrm{REG}}\left(\mathrm{s}^{-1}\right)$ & $4.94 \times 10^{-3}$ & $1.59 \times 10^{-3}$ & $8.22 \times 10^{-2}$ \\
$\%$ as NH & 1.1 & 4.8 & $2.3 \times 10^{-2}$ \\
$\%$ as NO & 100 \\
\hline
\end{tabular}

charge during the day, a common pattern in Mediterranean streams in summer due to high evapotranspiration by riparian trees (Butturini et al., 2002). These diel changes in temperature and discharge likely contributed to higher $\mathrm{NO}_{3}^{-}$uptake at day by respectively enhancing metabolic activity (Kaplan and Bott, 1989) and providing a greater ratio of streambed area to water volume (Butturini and Sabater, 1998). 


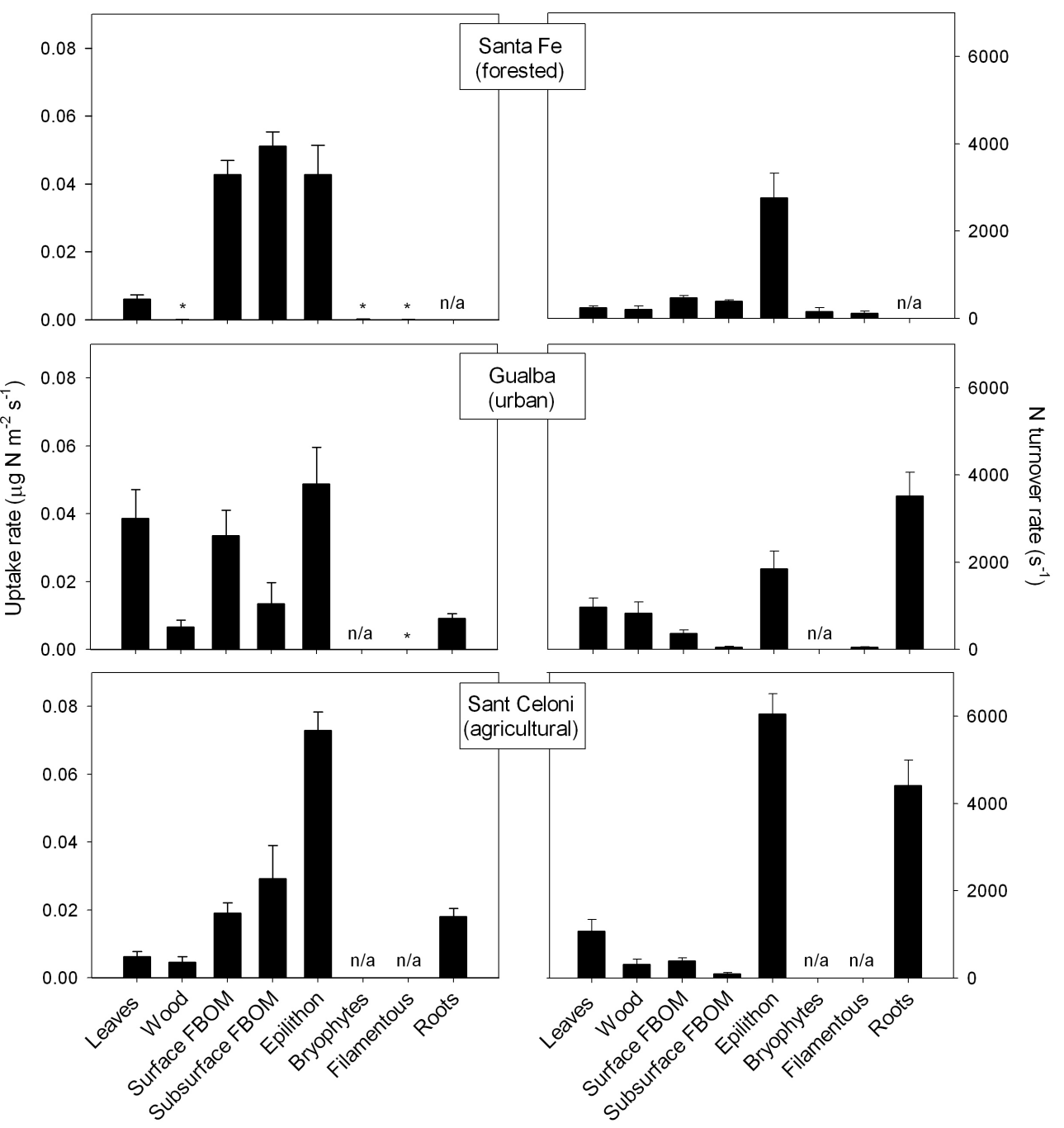

Fig. 4. Nitrate assimilatory uptake rates $($ mean $+\mathrm{SE})$ and $\mathrm{N}$ turnover rates (mean $+\mathrm{SE})$ of the different primary uptake compartments within each stream calculated with ${ }^{15} \mathrm{~N}$ content data from the post- $24 \mathrm{~h}$ sampling. Asterisks (*) represent uptake rates $<0.001 \mu \mathrm{g} \mathrm{m}^{-2} \mathrm{~s}-1$. Uptake compartments not found in a stream are marked as not available (n/a). Notice the same scale on the y-axes to facilitate comparisons among streams.

Although the number of streams in our study was limited, we expected $S_{W} \mathrm{NO}_{3}^{-}$and $U \mathrm{NO}_{3}^{-}$to increase and $V_{f} \mathrm{NO}_{3}^{-}$ to decrease with increasing $\mathrm{NO}_{3}^{-}$concentration due to saturation processes (Earl et al., 2006). However, the observed pattern was nearly opposite: $S_{W} \mathrm{NO}_{3}^{-}$was longest in the forested stream and shortest in the agricultural stream, both having the lowest and highest $\mathrm{NO}_{3}^{-}$concentrations, respectively. On the other hand, $V_{f} \mathrm{NO}_{3}^{-}$and $U \mathrm{NO}_{3}^{-}$were highest in the urban stream, which showed intermediate $\mathrm{NO}_{3}^{-}$ concentrations with respect to the other two streams.. The considerably lower discharge in the agricultural stream in comparison to the other streams may have contributed to the observed pattern in $S_{W} \mathrm{NO}_{3}^{-}$by increasing the contact surface between the sediments and the water column. However, results from $V_{f} \mathrm{NO}_{3}^{-}$and $U \mathrm{NO}_{3}^{-}$, which correct $S_{W}$
$\mathrm{NO}_{3}^{-}$for differences in stream size and $\mathrm{NO}_{3}^{-}$concentration, respectively (Webster and Valett, 2006), indicate that other factors were influencing $\mathrm{NO}_{3}^{-}$uptake in these streams. The notably lower water temperature in the forested stream may have contributed to the low GPP and ER, which may in turn have reduced biological $\mathrm{N}$ demand in this stream (Fellows et al., 2006). Based on temperature and metabolism rates, however, we would have expected a higher $\mathrm{N}$ demand in the agricultural stream than in the urban stream, which was not observed. A relatively greater standing stock of primary uptake compartments and higher solar radiation in the urban stream may partially explain its higher $\mathrm{NO}_{3}^{-}$demand relative to the agricultural stream. 


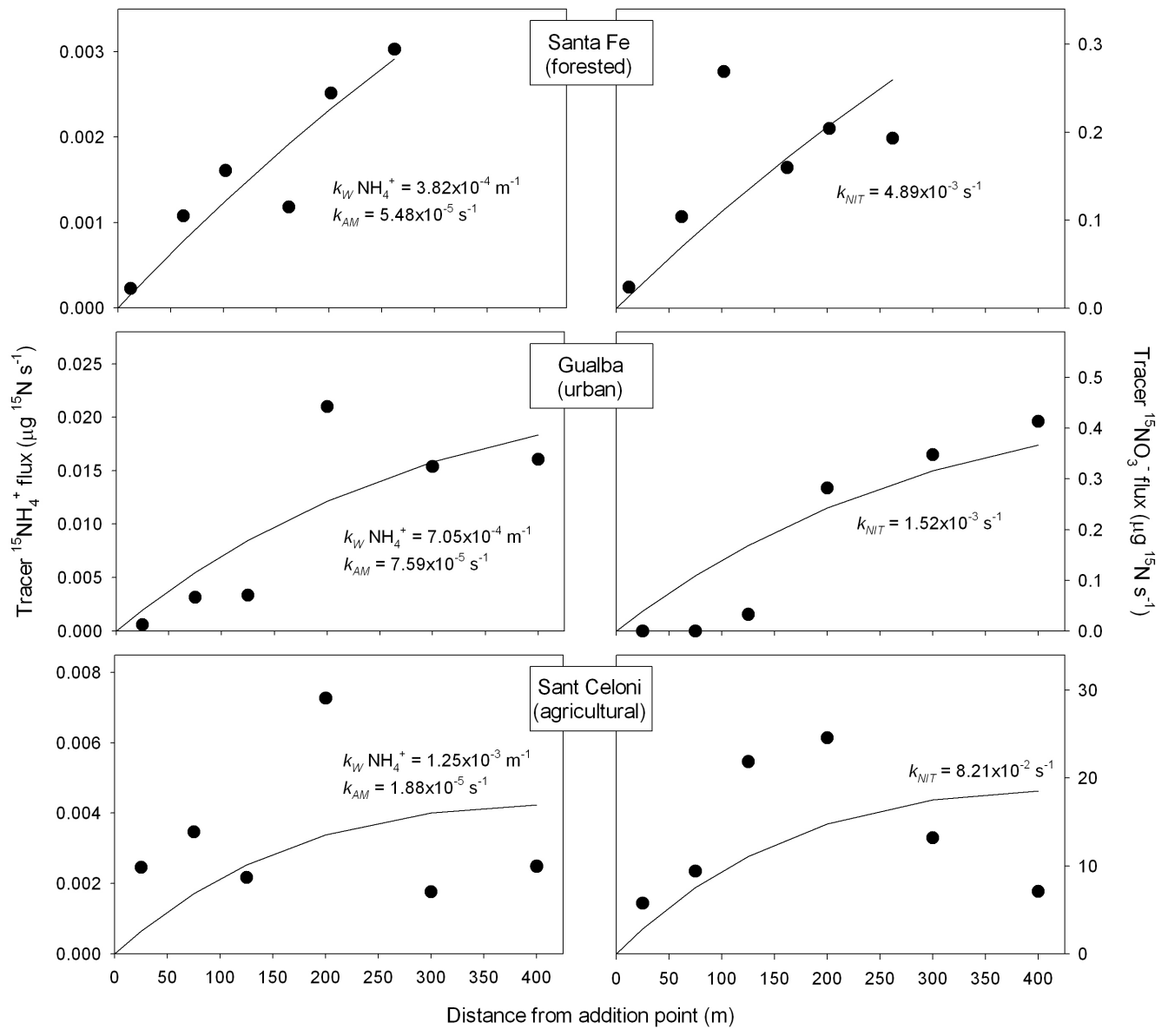

Fig. 5. Plot of the tracer ${ }^{15} \mathrm{NH}_{4}^{+}$(left) and tracer ${ }^{15} \mathrm{NO}_{3}^{-}$(right) flux versus distance downstream from the addition point with data from the post-24h sampling. Solid lines show the best fit of the ammonification-nitrification model to the tracer ${ }^{15} \mathrm{~N}$ flux data. The estimated parameters were: the fractional $\mathrm{NH}_{4}^{+}$release rate per unit time $\left(k_{\mathrm{AM}} ; \mathrm{s}^{-1}\right)$, the fractional $\mathrm{NH}_{4}^{+}$uptake rate per unit distance $\left(k_{W} \mathrm{NH}_{4}^{+}\right.$; $\left.\mathrm{m}^{-1}\right)$, and the fractional nitrification rate per unit time $\left(k_{\mathrm{NIT}} ; \mathrm{s}^{-1}\right)$.

Results from a previous study in these streams using $\mathrm{NH}_{4}^{+}$ enrichments during spring, at conditions of higher discharge and light availability than in the present study, showed that, in contrast to $\mathrm{NO}_{3}^{-}$, the efficiency to take up $\mathrm{NH}_{4}^{+}$was highest in the forested and lowest in the agricultural stream (von Schiller et al., 2008). In addition, values of $V_{f}$ for $\mathrm{NH}_{4}^{+}$ were greater than those found for $\mathrm{NO}_{3}^{-}$in this study, indicating that these streams take up $\mathrm{NH}_{4}^{+}$more efficiently than $\mathrm{NO}_{3}^{-}$. However, a comparison of both studies indicates that the magnitude of the preference for $\mathrm{NH}_{4}^{+}$over $\mathrm{NO}_{3}^{-}$may decrease in more $\mathrm{N}$ polluted streams with higher $\mathrm{NO}_{3}^{-}$and lower DO concentrations. In these conditions, relative demand for $\mathrm{NO}_{3}^{-}$may increase because it may be used as an electron acceptor in dissimilatory uptake processes such as denitrification. This is further supported by results from nutrient diffusing substrata experiments conducted in these streams during the same period as the present study (von Schiller et al., 2007).

\subsection{Comparison of $\mathrm{NO}_{3}^{-}$removal and retention pathways}

The importance of $\mathrm{NO}_{3}^{-}$removal over retention was highest in the agricultural stream, intermediate in the urban stream and lowest in the forested stream. This pattern coincided with the observed pattern of $\mathrm{NO}_{3}^{-}$concentration and was opposite to that of DO concentration. Assimilatory uptake accounted for all or most of total $\mathrm{NO}_{3}^{-}$uptake in the forested and the urban streams, respectively, whereas denitrification dominated total $\mathrm{NO}_{3}^{-}$uptake in the agricultural stream. However, similarly to $V_{f} \mathrm{NO}_{3}^{-}$, values of $V_{\mathrm{fDEN}}$ were in the lower range of values reported from streams subjected to various land uses across USA and Puerto Rico (Mulholland et al., 2008). In that study, denitrification accounted for a median of $16 \%$ of total $\mathrm{NO}_{3}^{-}$uptake and exceeded $45 \%$ of total uptake in a quarter of them (Mulholland et al., 2008). Despite a narrower $\mathrm{NO}_{3}^{-}$concentration range in our study, denitrification was highly variable among streams, accounting for 


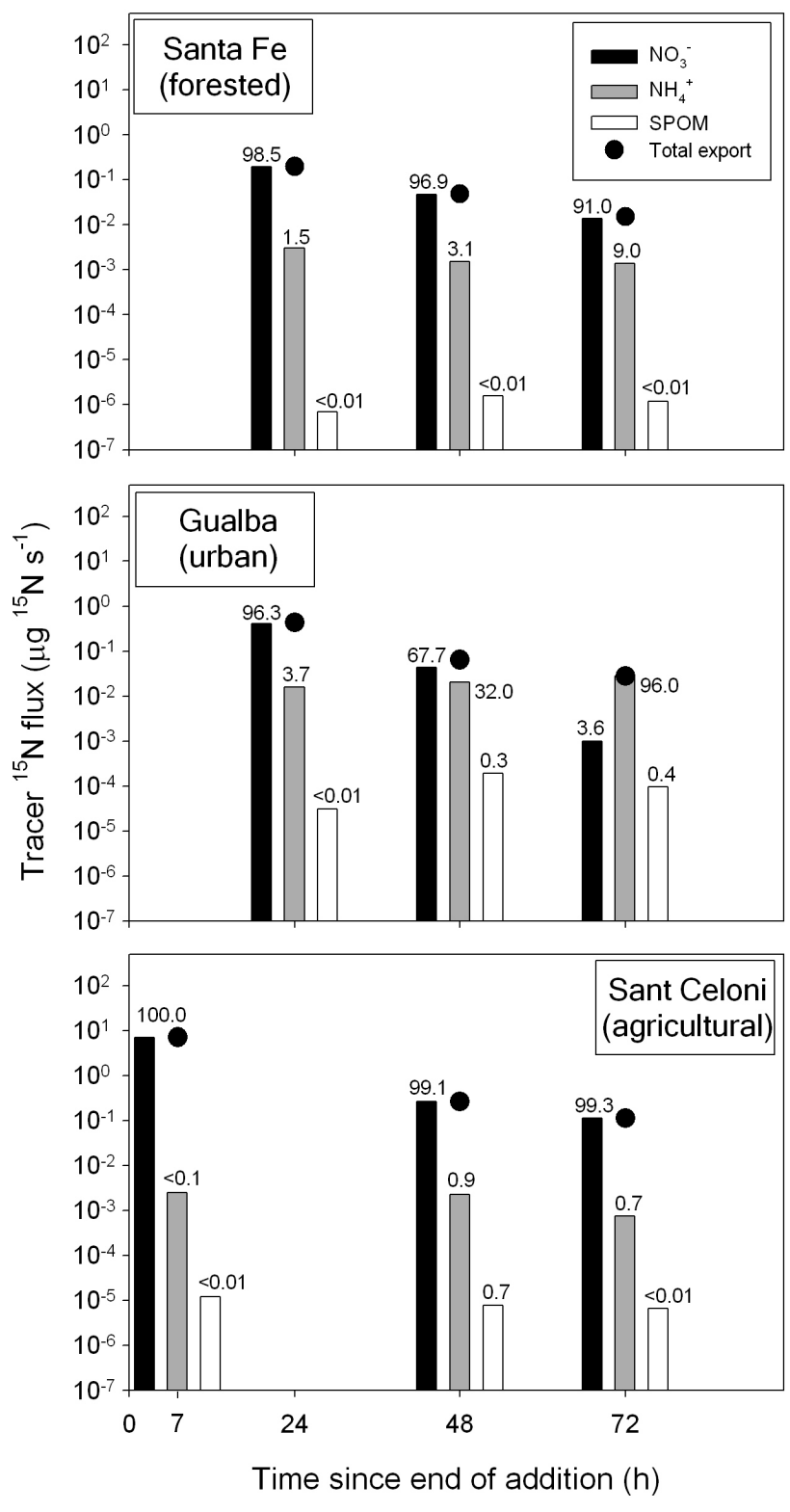

Fig. 6. Plot of the tracer ${ }^{15} \mathrm{~N}$ export as $\mathrm{NO}_{3}^{-}, \mathrm{NH}_{4}^{+}$and suspended particulate organic matter (SPOM) versus time since the end of the addition with data from the post- $24 \mathrm{~h}$, post- $48 \mathrm{~h}$, and post- $72 \mathrm{~h}$ samplings. Numbers on columns represent the percent contribution of each export pathway to total export within a stream at a given sampling time. Notice that the post- $24 \mathrm{~h}$ sampling was performed $7 \mathrm{~h}$ after the end of the addition in the agricultural stream.

$0 \%$ to $68 \%$ of total $\mathrm{NO}_{3}^{-}$uptake. However, denitrification results should be viewed with great caution because uncertainty in ecosystem denitrification is influenced by the magnitude and precision of the reaeration rate (Mulholland et al., 2004), and reaeration rates obtained with empirical models (e.g. surface renewal model) can differ substantially (Generaux and Hemond, 1992).
Differences in physical and chemical characteristics may explain the observed pattern in denitrification among the study streams. Ambient conditions in the agricultural stream (i.e. high temperature, dissolved inorganic nitrogen [DIN] and DOC, and low discharge and DO) likely enhanced denitrification as a $\mathrm{NO}_{3}^{-}$uptake process in this stream, as indicated in cross-system analyses (Piña-Ochoa and ÁlvarezCobelas, 2006). Conversely, ambient conditions in the urban, and especially in the forested stream, were not so favorable for denitrification, and assimilatory processes dominated total uptake in these streams. As Christensen et al. (1990) suggested, higher net heterotrophy (i.e. lower GPP:ER ratio) may additionally have promoted dissimilatory uptake in the agricultural stream by maintaining lower DO levels in the sediments.

Denitrification rates tended to be higher at day than at night in both streams in which denitrification was detected, this difference being more important in the urban stream. O'Brien et al. (2007) found the opposite pattern (i.e. higher denitrification at night than at day) in prairie streams located in Kansas (USA), likely due to the inhibitory effect of high algal photoautotrophic oxygen production during daylight in open-canopy streams. In contrast, our streams were well shaded and photoautotrophic activity was relatively unimportant, as indicated by the low GPP:ER ratios. Nevertheless, Mulholland et al. (2008) found no difference in denitrification between day and night, and a recent review of denitrification in aquatic ecosystems found no significant differences between light and dark conditions (Piña-Ochoa and ÁlvarezCobelas, 2006).

The main end product of denitrification was $\mathrm{N}_{2}$, except in the urban stream at night, when denitrification was detected only in the form of $\mathrm{N}_{2} \mathrm{O}$. Nevertheless, on average, $\mathrm{N}_{2} \mathrm{O}$ production accounted for $<3 \%$ of total stream denitrification, supporting results from previous studies indicating that stream denitrification consumes nearly the entire $\mathrm{N}_{2} \mathrm{O}$ intermediary (Mulholland et al., 2004, 2008; Beaulieau et al., 2008).

The proportion of total $\mathrm{NO}_{3}^{-}$assimilatory uptake (i.e. the difference between $k_{W} \quad \mathrm{NO}_{3}^{-}$and $k_{\mathrm{DEN}}$ ) accounted for by $k_{\mathrm{BIO}}$ was high in the forested and the agricultural stream, whereas only a small proportion of total $\mathrm{NO}_{3}^{-}$assimilatory uptake was accounted for by $k_{\mathrm{BIO}}$ in the urban stream. This underestimation was likely due to either errors in the sampling of standing stocks, alternative dissimilatory $\mathrm{NO}_{3}^{-}$uptake pathways (e.g., DNRA), rapid transfer of the retained $\mathrm{N}$ to higher trophic levels, or high regeneration rates of the retained N (Tank et al., 2000; Burgin and Hamilton, 2007). For this reasons, results from $\mathrm{NO}_{3}^{-}$assimilatory uptake should be viewed with great caution, especially in the urban stream.

The relative contribution of the different primary uptake compartments to $U_{\mathrm{BIO}}$ varied considerably among streams. Detritus compartments, especially FBOM, dominated standing stocks and $\mathrm{NO}_{3}^{-}$assimilatory uptake in the forested and 
urban stream as has been previously reported in studies from well-shaded streams with low autotrophic activity (e.g., Mulholland et al., 2000; Tank et al., 2000). Despite its small standing stocks, epilithon was the most important $\mathrm{NO}_{3}^{-}$uptake compartment in the agricultural stream and also contributed notably to $\mathrm{NO}_{3}^{-}$uptake in the other streams. Previous studies have emphasized the high $\mathrm{N}$ uptake capacity of epilithon even in well-shaded streams (e.g., Tank et al., 2000; Merriam et al., 2002). Although leaves were an important standing stock compartment in both the forested and the urban stream, they contributed considerably more to $\mathrm{NO}_{3}^{-}$uptake in the urban stream. An important part of leaf litter found in the urban stream was fresh due to the summer leaf fall, which is characteristic of Mediterranean streams affected by hydric stress (Sabater et al., 2001). Conversely, leaves found in the forested stream were old (i.e. from the previous autumn leaf fall) and highly decomposed at the time of study (von Schiller, personal observation). This observation was confirmed by the $\mathrm{C}: \mathrm{N}$ ratios of leaves, which were higher in the forested than in the urban stream. Small wood standing stocks characteristic of Mediterranean streams with young riparian vegetation (Sabater et al., 2001) were reflected in low contribution to total uptake by this detritus compartment. Similarly, autotrophic organisms such as bryophytes and filamentous algae showed small standing stocks and low uptake rates. In these streams, filamentous algae were in a decaying state during the experiments and are usually more abundant in spring, when light availability is higher, whereas bryophytes are relatively scarce during the whole year (von Schiller, personal observation).

Despite their small standing stock, submersed alder roots were an important uptake compartment, especially in the agricultural stream. Alders are known to be $\mathrm{N}$ fixers; however, our results suggest that in the study streams they can also use dissolved $\mathrm{N}$ directly from the stream water, thus contributing to increase stream $\mathrm{N}$ uptake. Since we did not sample non-submersed parts of the alders, we could not determine whether $\mathrm{NO}_{3}^{-}$was taken up by the trees or by biofilms growing on the root surface. Even if trees were taking up $\mathrm{NO}_{3}^{-}$, we would not know whether it was directly for nutrient use or indirectly through water transport. The role of riparian vegetation in stream $\mathrm{N}$ retention has been previously demonstrated using long-term ${ }^{15} \mathrm{~N}$ tracer additions in both arid (Schade et al., 2005) and temperate streams (Ashkenas et al., 2004). These results together with ours indicate that riparian vegetation may not only act as an effective filter for nutrients moving from the surrounding catchment to the stream (Naiman et al., 1997), but it may also contribute to nutrient movement in the opposite direction by taking up and retaining dissolved nutrients that are being transported in the stream water, thereby increasing whole-stream $\mathrm{N}$ retention. This stream-riparian linkage may be enhanced in arid and semi-arid regions, such as the study area, where riparian vegetation is strongly limited by water availability.

\subsection{Fate of retained $\mathrm{NO}_{3}^{-}$}

Labeled $\mathrm{NH}_{4}^{+}$released from stream benthic compartments was found shortly after the end of the addition, indicating that regeneration of the assimilated $\mathrm{NO}_{3}^{-}$was rapid in these streams. This $\mathrm{NH}_{4}^{+}$was likely released via excretion by aquatic organisms and mineralization of organic matter and labile organic molecules like aminoacids (Newbold, 1996). Total regeneration was highest in the agricultural stream, intermediate in the forested stream, and lowest in the urban stream. Results from the compartment-specific $\mathrm{N}$ turnover rates indicate that epilithon was the primary uptake compartment that most contributed to $\mathrm{N}$ regeneration in these streams. The low $\mathrm{C}: \mathrm{N}$ ratio of epilithon in comparison with detritus compartments, which indicates high metabolic activity and highly labile $\mathrm{N}$, may explain the observed result (Dodds et al., 2000). We also expected a high $\mathrm{N}$ turnover in other compartments dominated by primary producers showing a low $\mathrm{C}: \mathrm{N}$ ratio (i.e. filamentous algae and bryophytes). However, these compartments generally showed the lowest turnover in the study streams, likely due to their decaying state. In contrast, alder roots showed a high $\mathrm{N}$ turnover rate, but this probably was due to the combination of both $\mathrm{N}$ allocation from the roots to other parts of the plant and $\mathrm{N}$ regeneration back to the water column.

Most released $\mathrm{NH}_{4}^{+}$was rapidly transformed to $\mathrm{NO}_{3}^{-}$via nitrification within the experimental reach, indicating that ammonification and nitrification were strongly coupled in these streams. However, the proportion of $\mathrm{NH}_{4}^{+}$transformed into $\mathrm{NO}_{3}^{-}$differed among streams, being lowest in the urban stream. The produced $\mathrm{NO}_{3}^{-}$was then transiently retained again via assimilatory uptake by primary uptake compartments, permanently removed via denitrification, or exported downstream. As a result of rapid nitrification, most retained $\mathrm{N}$ was exported from the study reaches in the form of $\mathrm{NO}_{3}^{-}$. Export as $\mathrm{NH}_{4}^{+}$was more important in the urban than in the other streams due to the lower nitrification rate in the urban stream. Export as SPOM was relatively unimportant in the study streams, as has been observed in previous studies (Tank et al., 2000; Ashkenas et al., 2004). However, we must highlight that SPOM is expected to be retained for a longer time within the reach because it is subjected to more physical retention mechanisms than DIN. In fact, our results indicate that the proportion of retained $\mathrm{N}$ exported as SPOM tended to increase with time after the addition was stopped. We did not measure export as dissolved organic nitrogen (DON), although previous studies using ${ }^{15} \mathrm{~N}$ tracer additions have demonstrated that export of retained $\mathrm{N}$ as DON may exceed that of $\mathrm{NH}_{4}^{+}$or SPOM, but not that of $\mathrm{NO}_{3}^{-}$(Merriam et al., 2002; Ashkenas et al., 2004). 


\section{Conclusions}

This study provides evidence of fast $\mathrm{N}$ cycling through a strong coupling among uptake, regeneration and transformation processes in these Mediterranean streams. However, our results indicate that dominant pathways of $\mathrm{N}$ cycling are highly susceptible to local conditions. Despite similar standing stocks of primary uptake compartments and relatively small differences in stream physical and chemical characteristics; mostly influenced by the location and the land use type adjacent to the streams, we found large differences in $\mathrm{N}$ uptake, regeneration, transformation and export pathways among the study streams. Moreover, our results seem to indicate that permanent $\mathrm{NO}_{3}^{-}$removal via denitrification may be enhanced over temporary $\mathrm{NO}_{3}^{-}$retention via assimilatory uptake in heterotrophic human-altered streams characterized by high $\mathrm{NO}_{3}^{-}$and low DO concentrations. Changes in the relative importance of retention and removal may substantially influence the amount and form of $\mathrm{N}$ delivered to downstream and coastal ecosystems. Further studies addressing $\mathrm{N}$ retention, transformation and removal processes in streams located in different biomes and subjected to various human alterations are required to gain a complete understanding of $\mathrm{N}$ cycling and its controlling factors in fluvial ecosystems.

Acknowledgements. The authors would like to thank the LINX group for their help with the ${ }^{15} \mathrm{~N}$ addition procedures. Special thanks are due to W. H. McDowell and his research group for training D. von Schiller during his stay in Puerto Rico, to S. K. Hamilton for providing sampling material and analyzing the ${ }^{15} \mathrm{~N}_{2}$ samples, and to P. J. Mulholland and S. A. Thomas for helping with some of the calculations. We also thank M. Martí, C. Dinter, R. Ricart, M. Ribot and S. Pla for field and laboratory assistance, and A. Oltra for providing the map of the study sites. Financial support was provided by the Spanish Ministry of Education and Science, RENITRAC (ref: REN2002-03592/HID) and NICON (ref: CGL2005-07362-C02) projects, and the European Commission, EURO-LIMPACS (ref: GOCE-CT-2003-505540) project. The Laboratori d'Enginyeria Química i Ambiental (LEQUIA) provided additional financial support for the purchase of the ${ }^{15} \mathrm{~N}$ labeled nitrate. The Direcció del Parc Natural del Montseny (Diputació de Barcelona) allowed access to one of the sites during the experiment. D. von Schiller was supported by an I3P PhD scholarship from the Consejo Superior de Investigaciones Científicas (CSIC).

Edited by: T. J. Battin

\section{References}

Alexander R. B., Smith R. A., and Schwarz, G. E.: Effect of stream channel size on the delivery of nitrogen to the Gulf of Mexico, Nature, 403, 758-761, 2000.

Allan, J. D.: Stream ecology: structure and function of running waters, Kluwer Academic Publishers, Dordrecht, The Netherlands, 388 pp., 1995.
Alvarez-Cobelas, M., Rojo, C., and Angeler D. G.: Mediterranean limnology: current status, gaps and the future, J. Limnol., 64, 13-29, 2005.

APHA: Standard methods for the examination of water and wastewater, American Public Health Association, Washington, USA, 1995.

Ashkenas, L. R., Johnson, S. 1., Gregory, S. V., Tank, J. L., and Wollheim, W. M.: A stable isotope study of nitrogen uptake and transformation in an old growth forest stream, Ecology, 85, 1725-1739, 2004.

Beaulieu, J. J., Arango, C. P., Hamilton, S. K., and Tank, J. L.: The production and emission of nitrous oxide from headwater streams in the Midwestern United States, Glob. Change Biol., 14, 878-894, 2008.

Bernot, M. J. and Dodds, W. K.: Nitrogen retention, removal, and saturation in lotic ecosystems, Ecosystems, 8, 442-453, 2005.

Bernot, M. J., Tank, J. L., Royer, T. V., and David, M. B.: Nutrient uptake in streams draining agricultural catchments of the Midwestern United States, Freshw. Biol., 51, 499-509, 2006.

Böhlke, J. K., Harvey, J. W., and Voytek, M. A.: Reach-scale isotope tracer experiment to quantify denitrification and related processes in a nitrate-rich stream, midcontinent United States, Limnol. Oceanogr., 49, 821-838, 2004.

Bott T. L.: Primary productivity and community respiration, in: Methods in stream ecology, edited by: Hauer, F. R., and Lamberti, G. A., Academic Press, San Diego, CA, USA, 663-690, 2006.

Burgin A. J. and Hamilton S. K.: Have we overemphasized the role of denitrification in aquatic ecosystems? A review of nitrate removal pathways, Front. Ecol. Environ., 5, 89-96, 2007.

Butturini, A. and Sabater F.: Ammonium and phosphate retention in a Mediterranean stream: hydrological versus temperature control, Can. J. Fish. Aquat. Sci., 55, 1938-1945, 1998.

Butturini, A., Bernal, S., Sabater, S., and Sabater, F.: The influence of the riparian-hyporheic zone on the hydrological responses in an intermittent stream, Hydrol. Earth Syst. Sci., 6, 515-525, 2002, http://www.hydrol-earth-syst-sci.net/6/515/2002/.

Camargo, J. A. and Alonso, A.: Ecological and toxicological effects of inorganic nitrogen pollution in aquatic ecosystems: a global assessment, Environ. Int., 32, 831-849, 2006.

Christensen, P. B., Nielsen, L. P., Sorensen, J., and Revsbech, N. P.: Denitrification in nitrate-rich streams: diurnal and seasonal variation related to benthic oxygen metabolism, Limnol. Oceanogr., 35, 640-651, 1990.

Davis, J. C. and Minshall, G. W.: Nitrogen and phosphorus uptake in two Idaho (USA) headwater wilderness streams, Oecologia, 119, 247-255, 1999.

Dodds, W. K., Evans-White, M. A., Gerlanc, N. M., Gray, L., Gudder, D. A., Kemp, M. J., López, A. L., Stagliano, D., Strauss, E. A., Tank, J. L., Whiles, M. R., and Wollheim, W. M. Quantification of the Nitrogen Cycle in a Prairie Stream, Ecosystems, 3, 574-589, 2000.

Dodds, K. D., López, A. L., Bowden, W. D., Gregory, S. V., Grimm, N. B., Hamilton, S. K., Hershey, A. E., Martí, E., McDowell, W. H., Meyer, J. L., Morrall, D., Mulholland, P. J., Peterson, B. J., Tank, J. L., Valett, H. M., Webster, J. R., and Wollheim, W. M.: $\mathrm{N}$ uptake as a function of concentration in streams. J. North Am. Benthol. Soc., 21, 206-220, 2002.

Earl, S. R., Valett, H. M., and Webster J. R.: Nitrogen saturation in 
stream ecosystems, Ecology, 87, 3140-3151, 2006.

Ensign, S. H. and Doyle M. W.: In-channel transient storage and associated nutrient retention: evidence from experimental manipulations. Limnol. Oceanogr., 50, 1740-1751, 2005.

Fellows, C. S., Valett, H. M., Dahm,C. N., Mulholland, P. J., and Thomas, S. A..: Coupling nutrient uptake and energy flow in headwater streams, Ecosystems, 9, 788-804, 2006.

Fowler, J. and Cohen, L.: Practical statistics for field biology, Wiley \& Sons, Chichester, UK, 1990.

Genereux, D. P. and Hemond, H. F.: Determination of gas exchange rates for a small stream on Walker Branch Watershed, Tenessee, Water Resour. Res., 28, 2365-2374, 1992.

Grimm, N. B., Sheibley, R. W., Crenshaw, C. L., Dahm, C. N., Roach, W. J., and Zeglin, L. H.: N retention and transformation in urban streams, J. North Am. Benthol. Soc., 24, 626-642, 2005.

Gücker, B. and Pusch, M. T.: Regulation of nutrient uptake in eutrophic lowland streams, Limnol. Oceanogr., 51, 1443-1453, 2006.

Hall, R. O., Peterson, B. J., and Meyer, J. L.: Testing a nitrogencycling model of a forest stream by using a nitrogen-15 tracer addition, Ecosystems, 1, 283-298, 1998.

Hall, R. O., Bernhardt, E. S., and Likens G. E.: Relating nutrient uptake with transient storage in forested mountain streams, Limnol. Oceanogr. 47, 255-265, 2002.

Hamilton, S. K. and Ostrom, N. E.: Measurement of the stable isotope ratio of dissolved N2 in $15 \mathrm{~N}$ tracer experiments, Limnol. Oceanogr. Meth., 5, 233-240, 2007.

Hoellein, T. J., Tank, J. L., Rosi-Marshall, E. J., Entrekin, S. A., and Lamberti, G. A.: Controls on spatial and temporal variation of nutrient uptake in three Michigan headwater streams, Limnol. Oceanogr., 52, 1964-1977, 2007.

Holmes, R. M., Jones, J. B.. Fisher, S. G, and Grimm, N. B.: Denitrification in a nitrogen-limited stream ecosystem, Biogeochem., 33, 125-146, 1996.

Holmes, R. M., McClelland, J. W., Sigman, D. M., Fry, B., and Peterson, B. J.: Measuring ${ }^{15} \mathrm{~N}-\mathrm{NH}_{4}^{+}$in marine, estuarine and fresh waters: an adaptation of the ammonia diffusion method for samples with low ammonium concentrations, Mar. Chem., 60, 235-243, 1998.

Inwood, S. E., Tank, J. L., and Bernot, M. J.: Patterns of denitrification associated with land use in 9 midwestern headwater streams, J. North Am. Benthol. Soc., 24, 227-245. 2005.

Kaplan, L. A. and Bott, T. L.: Diel fluctuations in bacterial activity on streambed substrata during vernal algal blooms: effects of temperature, water chemistry, and habitat, Limnol. Oceanogr., 34, 718-733, 1989.

Kemp, M. J. and Dodds, W. K.: The Influence of ammonium, nitrate, and dissolved oxygen concentrations on uptake, nitrification, and denitrification rates associated with prairie stream substrata, Limnol. Oceanogr., 47, 1380-1393, 2002.

Merriam, J. L., McDowell, W. H., Tank, J. L., Wollheim, W. M., Crenshaw, C. L., and Johnson, S. L.: Characterizing nitrogen dynamics, retention and transport in a tropical rainforest stream using an in situ ${ }^{15} \mathrm{~N}$ addition. Freshw. Biol., 47, 143-160, 2002.

Mulholland, P. J., Tank, J. L., Sanzone, D. M., Wollheim, W. M., Peterson, B. J., Webster, J. R., and Meyer, J. L.: Nitrogen cycling in a forest stream determined by a ${ }^{15} \mathrm{~N}$ tracer addition, Ecol. Monogr., 70, 471-493, 2000.

Mulholland, P. J., Tank, J. L., Webster, J. R., Bowden, W. D., Dodds,
K. D., Gregory, S. V., Grimm, N. B., Hamilton, S. K., Johnson, S. L., Martí, E., McDowell, W. H., Merriam, J. L., Meyer, J. L., Peterson, B. J., Valett, H. M., and Wollheim, W. M.: Can uptake length in streams be determined by nutrient addition experiments? Results from an interbiome comparison study, J. North Am. Benthol. Soc., 21, 544-560, 2002.

Mulholland, P. J., Valett H. M., Webster, J. R. Thomas, S. A., Cooper, L. W., Hamilton, S. K., and Peterson, B. J.: Stream denitrification and total nitrate uptake rates measured using a field ${ }^{15} \mathrm{~N}$ tracer addition approach, Limnol. Oceaonogr., 49, 809-820, 2004.

Mulholland, P. J., Thomas S. A., Valett H. M., Webster, J. R., and Beaulieu, J. J.: Effects of light on $\mathrm{NO}_{3}^{-}$uptake in small forested streams: diurnal and day-to-day variations. J. North Am. Benthol. Soc., 25, 583-595, 2006.

Mulholland, P.J., Helton, A. M., Poole, G. C., Hall, R. O., Hamilton, S. K., Peterson, B. J., Tank, J. L., Ashkenas, L. R., Cooper, L. W., Dahm, C. N., Dodds, W. K., Findlay, S. E., Gregory, S. V., Grimm, N. B., Johnson, S. L., Mcdowell, W. H., Meyer, J. L., Valett, H. M., Webster, J. R., Arango, C. P., Beaulieu, J. J., Bernot, M. J., Burgin, A. J., Crenshaw, C. L., Johnson, L. T., Niederlehner, B. R., O’Brien, J. M., Potter, J. D., Sheibley, R. W., Sobota, D. J., and Thomas, S. M.: Stream denitrification across biomes and its response to anthropogenic nitrate loading, Nature, 452, 202-205, 2008.

Naiman, R. J. and Decamps, H.: The ecology of interfaces: riparian zones, Annu. Rev. Ecol. Syst., 28, 621-658, 1997.

Newbold, J. D.: Cycles and spirals of nutrients, in: River flows and channel forms, edited by: Petts, G, and Calow C., Blackwell, Oxford, UK, 130-159, 1996.

O'Brien, J. M., Dodds, W. K., Wilson, K. C., Murdock, J. N., and Eichmiller, J.: The saturation of $\mathrm{N}$ cycling in Central Plains streams: ${ }^{15} \mathrm{~N}$ experiments across a broad gradient of nitrate concentrations, Biogeochem., 84, 31-49, 2007.

Owens, M.: Measurements on non-isolated natural communities in running waters, in: A manual on Methods for measuring primary production in aquatic environments, edited by: Vollenweider, $\mathrm{R}$ A., Blackwell, Oxford, UK, 111-119, 1974.

Peterson, B. J., Bahr, M., and Kling, G. W.: A tracer investigation of nitrogen cycling in a pristine tundra river, Can. J. Fish. Aquat. Sci., 54, 2361-2367, 1997.

Peterson, B. J., Wollheim, W. M., Mulholland, P. J., Webster, J. R., Meyer, J. L., Tank, J. L., Martí, E., Bowden, W. D., Valett H. M., Hershey, A. E., McDowell, W. H., Dodds, K. D., Hamilton, S. K., Gregory, S. V., and Morrall, D.: Control of nitrogen export from watersheds by headwater streams, Science, 292, 8690, 2001.

Piña-Ochoa, E. and Álvarez-Cobelas, M.: Denitrification in aquatic environments: a cross-system analysis, Biogeochem., 81, 11130, 2006.

Ruggiero, A., Solimini, A. G., and Carchini, G.: Effects of a wastewater treatment plant on organic matter dynamics and ecosystem functioning in a Mediterranean stream, Annal. Limnol., 42, 97-107, 2006.

Runkel, R. L.: One dimensional transport with inflow and storage (OTIS): a solute transport model for streams and rivers. Water Resources Investigations Report 98-4018, US Geological Survey, Denver, USA, 1998.

Sabater, S., Bernal, S., Butturini, A., Nin, E., and Sabater, F.: Wood 
and leaf debris input in a Mediterranean stream: the influence of riparian vegetation, Arch. Hydrobiol., 153, 91-102, 2001.

Schade, J. D., Welter, J. R., Martí, E., and Grimm, N. B.: Hydrologic exchange and $\mathrm{N}$ uptake by riparian vegetation in an aridland stream. J. North Am. Benthol. Soc., 24, 19-28, 2005.

Seitzinger, S. P.: Denitrification in freshwater and coastal marine ecosystems: ecological and geochemical significance, Limnol. Oceanogr., 33, 702-724, 1988.

Sigman, D. M., Altabet, M. A., Michener, R., McCorkle, D. C., Fry, B., and Holmes, R. M.: Natural abundance-level measurement of the nitrogen isotopic composition of oceanic nitrate: an adaptation of the ammonia diffusion method, Mar. Chem., 57, 227-242, 1997.

Simon, K. S., Townsend, C. R., Biggs, B. J., and Bowden, W. D.: Temporal variation of $\mathrm{N}$ and $\mathrm{P}$ uptake in 2 New Zealand streams, J. North Am. Benthol. Soc., 24, 1-18, 2005.

Simon, K. S., Niyogi, D. K., Frew, R. D. and Townsend, C. R.: Nitrogen dynamics in grassland streams along a gradient of agricultural development, Limnol. Oceanogr., 52, 1246-1257, 2007.

Stream Solute Workshop: Concepts and methods for assessing solute dynamics in stream ecosystems, J. North Am. Benthol. Soc., 9, 95-119, 1990.
Tank, J. L., Meyer, J. L., Sanzone, D. M., Mulholland, P. J., Webster, J. R., Peterson, B. J., Wollheim, W. M., and Leonard, N. E.: Analysis of nitrogen cycling in a forest stream during autumn using a ${ }^{15} \mathrm{~N}$-tracer addition, Limnol. and Oceanogr., 45, 10131029, 2000.

von Schiller, D., Martí, E., Riera, J. L., and Sabater, F.: Effects of nutrients and light on periphyton biomass and nitrogen uptake in Mediterranean streams with contrasting land uses, Freshw. Biol., 52, 891-906, 2007.

von Schiller, D., Martí, E., Riera, J. L., Ribot, M., Marks, J. C., and Sabater, F.: Influence of land use on stream ecosystem function in a Mediterranean catchment, Freshw. Biol., 53, 2600-2612, 2008.

Wagner, B. J. and Harvey, J. W.: Experimental design for estimating parameters of rate-limited mass transfer: analysis of stream transfer studies, Water Resour. Res., 33, 1731-1741, 1997.

Webster, J. R. and Valett, H. M.: Solute dynamics, in: Methods in stream ecology, edited by: Hauer, F. R. and Lamberti, G. A., Academic Press, San Diego, CA, USA, 169-185, 2006. 